\title{
Retinal Vascular Abnormalities and Microglia Activation in Mice with Deficiency in Cytochrome P450 46A1-Mediated Cholesterol Removal
}

Aicha Saadane, ${ }^{*}$ Natalia Mast, ${ }^{*}$ George Trichonas, ${ }^{*}$ Dibyendu Chakraborty, ${ }^{\dagger}$ Sandra Hammer, ${ }^{\ddagger}$ Julia V. Busik, ${ }^{\ddagger}$ Maria B. Grant, and Irina A. Pikuleva*

From the Department of Ophthalmology and Visual Sciences, * the University Hospitals, Case Western Reserve University, Cleveland, Ohio; the Department of Ophthalmology, ${ }^{\dagger}$ University of Alabama, Birmingham, Alabama; and the Department of Physiology, ${ }^{\ddagger}$ Michigan State University, East Lansing, Michigan

\author{
Accepted for publication \\ October 15, 2018. \\ Address correspondence to \\ Irina A. Pikuleva, Ph.D., \\ Department of Ophthalmology \\ and Visual Sciences, Case \\ Western Reserve University, \\ 2085 Adelbert Rd., r. 303a, \\ Cleveland, OH 44106. E-mail: \\ iap8@case.edu.
}

\begin{abstract}
CYP46A1 is the cytochrome P450 enzyme that converts cholesterol to 24-hydroxycholesterol, a cholesterol elimination product and a potent liver $X$ receptor (LXR) ligand. We conducted retinal characterizations of $\mathrm{Cyp}_{\mathrm{C}} \mathrm{Ga1} 1^{-/-}$mice that had normal fasting blood glucose levels but up to a 1.8-fold increase in retinal cholesterol. The retina of $\mathrm{Cyp} 46 \mathrm{ar}^{-/-}$mice exhibited venous beading and tortuosity, microglia/macrophage activation, and increased vascular permeability, features commonly associated with diabetic retinopathy. The expression of $L x r \alpha$ and $L x r \beta$ was increased in both the whole Cyp46a1-/retina and retinal macroglia/macrophages. The LXR-target genes were affected as well, primarily in activated microglial cells and macrophages. In the latter, the LXR-transactivated genes (Abca1, Abcg1, Apod, Apoe, Mylip, and Arg2) were up-regulated; similarly, there was an up-regulation of the LXRtransrepressed genes (Ccl2, Ptgs2, Cxcl1, Il1b, Il6, Nos2, and Tnfa). For comparison, gene expression was investigated in bone marrow-derived macrophages from Cyp46a1 ${ }^{-/-}$mice as well as retinal and

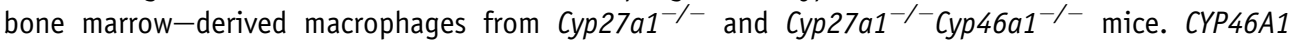
expression was detected in retinal endothelial cells, and this expression was increased in the proinflammatory environment. Retinal Cyp46a1 ${ }^{-/-}$phosphoproteome revealed altered phosphorylation of 30 different proteins, including tight junction protein zonula occludens 1 and aquaporin 4. Collectively, the data obtained establish metabolic and regulatory significance of CYP46A1 for the retina and suggest pharmacologic activation of CYP46A1 as a potential therapeutic approach to dyslipidemia-induced retinal damage. (Am J Pathol 2019, 189: 405-425; https://doi.org/10.1016/j.ajpath.2018.10.013)
\end{abstract}

Changes in retinal microcirculation are the early manifestations of diabetic retinopathy, the most common microvascular complications in type 1 diabetes and type 2 diabetes. $^{1-3}$ These changes include retinal microaneurysms, capillary nonperfusion and degeneration, venous beading and looping, intraretinal microvascular abnormalities (large-caliber shunt vessels within nonperfused regions of the capillary bed), excessive vasopermeability, retinal edema, and impairment of neural function. ${ }^{1,3}$ Remarkably, increased vascular permeability, dilation, nonperfusion, capillary degeneration, and arteriovenous shunts were observed in the retina of Cyp27a1 ${ }^{-/-}{\text {Cyp } 46 a 1^{-/-}}$mice $^{4}$ but not Cyp27a1 ${ }^{-/-}$mice, the two genotypes that had normal blood glucose levels but increased total retinal cholesterol. ${ }^{4}$

Cytochrome P450 27A1 (CYP27A1) is a sterol 27hydroxylase, ${ }^{5}$ whereas cytochrome P450 46A1 (CYP46A1) catalyzes cholesterol 24-hydroxylation. ${ }^{6}$ Both $\mathrm{P} 450$ s are expressed in the retina ${ }^{7-9}$ and are important for retinal cholesterol elimination. ${ }^{4,10}$ CYP27A1 is ubiquitous and is

Supported in part by NIH grants EY025383 (M.B.G. and J.V.B.), EY018383 (I.A.P.), and EY11373 (I.A.P.). The Visual Sciences Research Center Core Facilities was supported by NIH grant P30 EY11373.

Disclosures: None declared. 
highly abundant in the photoreceptor inner segments, Muller cells, and retinal pigment epithelium (RPE). ${ }^{11}$ CYP46A1 is less abundant in the retina ${ }^{7}$ and is mainly found in the neurons of the ganglion cell layer with a lower expression in the RPE. ${ }^{12}$ CYP46A1 and CYP27A1 produce 24-hydroxycholesterol (24HC) and 27-hydroxycholesterol (27HC), respectively, oxysterols, which are the transport forms of cholesterol ${ }^{9,13}$ from the retina to the systemic circulation. In addition, $24 \mathrm{HC}$ and $27 \mathrm{HC}$ are biologically active molecules that can interact with different regulatory proteins, including the liver $\mathrm{X}$ receptors (LXRs), a family of transcription factors. ${ }^{14} 24 \mathrm{HC}$ is a more potent LXR agonist than $27 \mathrm{HC}^{14}$; hence, we hypothesized that some of the abnormalities in Cyp27a1 ${ }^{-/-}$Cyp $46 a 1^{-/-}$mice were due to deficiency in CYP46A1 and a lack of 24HC activation of LXR. Indeed, $L x r \alpha / \beta^{-1-}$ mice showed vascular changes similar to those observed in the diabetic retina with increases in acellular capillaries despite the lack of metabolic dysfunction. ${ }^{15}$ Also, the expression of $L x r$ was shown to be significantly decreased in diabetic human retinas and in a type 2 diabetes animal model. ${ }^{16}$ Conversely, LXR activation by synthetic ligands was found to prevent retinal inflammation and diabetic retinopathy in diabetic animal models ${ }^{15,16}$ and to reduce proinflammatory macrophage activity. ${ }^{16}$

There are two LXR isoforms, LXR $\alpha$ and LXR $\beta$, that share high sequence identity (approximately $80 \%$ ) and are activated by the same ligands, typically oxygenated metabolites of cholesterol (eg, 24HC and 27HC) as well as cholesterol precursor desmosterol. ${ }^{14,17,18}$ LXR $\beta$ is ubiquitous, whereas $\mathrm{LXR} \alpha$ is tissue specific and is highly expressed in the liver, intestine, kidney, adipose tissue, and macrophages. ${ }^{19-21}$ Activation of LXRs leads either to gene transactivation or to gene transrepression. In transactivation, the basal condition is gene silencing by a complex of LXR with retinoid X receptor and corepressors bound to the promoter of the target gene. ${ }^{22}$ Ligand binding to LXR leads to release of corepressors in exchange for coactivators, thus initiating gene transcription. ${ }^{23}$ Many of the cholesterol-related genes [eg, ATP-binding cassette subfamily members A1 (Abcal) and G1 (Abcgl), apolipoprotein E (Apoe), inducible degrader of low-density lipoprotein receptor (Idol; official name, Mylip), and sterol regulatory element-binding protein 1c (Srebplc)] along with the genes involved in fatty acid synthesis [eg, elongation of long chain fatty acids family member 5 (Elovl5), fatty acid synthase (Fasn), fatty acid desaturase 2 (Fads2), and stearoyl-coenzyme A desaturases 1 and 2 (Scdl and $S c d 2$, respectively)] as well as other processes [eg, apoptosis inhibitor of macrophages (Aim), apolipoprotein D (Apod), arginase 2 (Arg2), glucose transporter type 4 (Glut4), and Mer receptor tyrosine kinase (Mertk)] are regulated by this mechanism. ${ }^{24,25}$ In transrepression, ligand binding leads to LXR sumoylation, which prevents the corepressor release and gene expression. ${ }^{26}$ This mechanism, shown to be operative in the liver and macrophages, blocks the transcription of $\mathrm{NF}-\kappa \mathrm{B}$ and other transcription factors and thereby the expression of the proinflammatory genes [eg, C-C motif chemokine 2 ( $C c l 2)$, prostaglandin $\mathrm{G} / \mathrm{H}$ synthase 2 (Cox-2; official name, Ptgs2), C-X-C motif chemokine ligand 1 (Cxcl1), IL-1 $\beta$ (Illb), IL-6 (Il6), inducible nitric oxide synthase (iNos), and tumor necrosis factor- $\alpha$ (Tnfa)], which are controlled by these factors. ${ }^{25-28}$

LXR $\alpha$ and LXR $\beta$ appear to be largely interchangeable in transactivation, with their contribution determined by relative expression level. ${ }^{29}$ However, in macrophages, LXR $\alpha$ may be more robust at transactivation and $\operatorname{LXR} \beta$ more potent at basal target repression. ${ }^{29} \operatorname{LXR} \alpha$ and LXR $\beta$ are both present in the neural retina and RPE and were immunolocalized to retinal layers: LXR $\beta$ appears to be ubiquitous, and $\operatorname{LXR} \alpha$ seems to be expressed in the cells of the ganglion cell layer and RPE. ${ }^{83}$ However, knowledge of cell-specific retinal LXR localizations is still lacking, including retinal endothelial cells and microglia, which may be missed on retinal cross sections because of the small numbers of these cells. Herein, we characterized the ocular phenotype of Cyp46a1 ${ }^{-1-}$ mice and obtained evidence that both metabolic and regulatory CYP46A1 activities are of significance for the retina and retinal blood vessels. We also performed multicolor immunohistochemistry labeling of vascular endothelial cells and CYP46A1. Our findings suggest that CYP46A1 may represent a new pharmacologic target for early-stage diabetic retinopathy treatment.

\section{Materials and Methods}

\section{Animals}

Animals were 6- to 9-month-old female or male mice. In both sexes, retinal vascular abnormalities on fluorescein angiography (FA) were detected starting from the age of 6 months. Furthermore, electroretinography (ERG) responses, conducted for both sexes at 6 months of age, were similar, as were the levels of mouse retinal and serum sterols. Hence, all subsequent experiments used male mice. Cyp46al $^{+-}$mice (on the mixed C57BL/6J; 129S6/SvEv background) were provided by Dr. David Russell (UT Southwestern, Dallas, TX). ${ }^{31}$ Cyp $27 a 1^{+/-}$mice (on the C57BL/6J background) were provided by Dr. Sandra Erickson (University of California, San Francisco, San Francisco, CA). ${ }^{32}$ The heterozygous animals obtained were crossed to generate the Cyp46a1 ${ }^{-/-}$, Cyp46a1 ${ }^{+/+}$, Cyp27a1 ${ }^{-1-}$, and Cyp27a1 ${ }^{+/+}$breeding pairs, which established the Cyp46a1 ${ }^{-/-}, C_{p y} 46 a 1^{+/+}, C_{y p 27 a 1^{-/}}$, and Cyp27a1 $1^{+/+}$colonies. The Cyp27a1 ${ }^{-1-}{\text { Cyp } 46 a 1^{-/}}^{-1}$ strain and $C y p 27 a^{+/+} C_{y p} 46 a 1^{+/+}$controls were generated by crossing Cyp27al ${ }^{+/-}$and Cyp46a1 ${ }^{+/-}$mice. $^{4}$ All mice were free of the $\mathrm{Crbl}^{\mathrm{rd}}$ mutation, which was bred out of our colonies. Cyp46a1 $1^{-1-}$ mice had normal fertility, body weight, food consumption, and appearance/weight of difference organs (data are not shown), consistent with previous genotype characterizations. ${ }^{31,33}$ All animals were maintained on a standard 12-hour light (approximately 10 lux)-dark cycle and were fed standard rodent chow and 
water ad libitum. All animal procedures were approved by the Case Western Reserve University (Cleveland, $\mathrm{OH}$ ) Institutional Animal Care and Use Committee and conformed to recommendations of the American Veterinary Association Panel on Euthanasia and the Association for Research in Vision and Ophthalmology.

\section{ERG}

ERG was performed as previously described. ${ }^{4}$ The scotopic a- and b-waves or the photopic b-wave was recorded in response to strobe flash stimuli presented after overnight dark adaptation (scotopic) or adaptation to a steady adapting field (photopic).

\section{FA}

FA was as described ${ }^{10}$ after a bolus (0.1-mL) i.p. injection of $1.6 \%$ sodium fluorescein in phosphate-buffered saline (PBS).

\section{Serum Chemistry and Glucose Tolerance Test}

Mice were fasted overnight and anesthetized via i.p. injection of $80 \mathrm{mg} / \mathrm{kg}$ ketamine (Fort Dodge Animal Health, Overland Park, KS) and $15 \mathrm{mg} / \mathrm{kg}$ xylazine (Akorn Inc., Lake Forest, IL) in PBS, pH 7.4. Blood was withdrawn via cardiac puncture and used for serum isolation, as described. ${ }^{34}$ Serum was analyzed for total cholesterol, high-density lipoprotein cholesterol, lowdensity lipoprotein cholesterol, triglycerides, and free fatty acids by Marshfield Labs (Marshfield, WI). For the glucose tolerance test, mice were fasted overnight and injected with a solution of $50 \%$ D-glucose ( $2 \mathrm{~g} / \mathrm{kg}$ body weight; Hospira, Lake Forest, IL) into the peritoneum. The blood was withdrawn from the tail vein and assayed for glucose by an Elite XL Glucometer (Bayer Contour, Parsippany, NJ) before and after the injection (30,60, 120, and 150 minutes).

\section{Retinal Isolation and Sterol Quantifications}

Retinal isolation and processing were as described, ${ }^{4}$ as are subsequent sterol quantifications by isotope dilution gas chromatography-mass spectroscopy. ${ }^{9}$

\section{Isolation and Treatment of RMMs and BMDMs}

Primary retinal microglia/macrophages (RMMs) and bone marrow-derived macrophages (BMDMs) were prepared from 1.5- to 2.5-month-old 8 to 12 male and female mice of the same genotype, as described ${ }^{35}$ with the following modifications. After isolation, mouse eyes were first placed in PBS containing $1 \%$ of penicillin/streptomycin (ThermoFisher, Waltham, MA) and then transferred to the ice-cold Dulbecco's modified Eagle's medium (DMEM; ThermoFisher) supplemented with $1 \%$ of penicillin/streptomycin. Next, eyes were cleaned from the connectives tissues and incubated for 30 minutes at $37^{\circ} \mathrm{C}$ and $60 \mathrm{rpm}$ shaking in DMEM containing 2\% dispase (Invitrogen, Waltham, MA) and $100 \mathrm{mg} / \mathrm{mL}$ collagenase IV (Invitrogen). The cornea, lens, and vitreous were removed, and the retinas were isolated from the eye cup under a surgical microscope (High Illuminator NI-5; Nikon Instruments Inc., Melville, NY) using tweezers. The retinas were then placed back in DMEM containing $2 \%$ dispase and $100 \mathrm{mg} / \mathrm{mL}$ collagenase IV and incubated for additional 15 minutes at $37^{\circ} \mathrm{C}$ and 60 rpm shaking. The tissue was transferred to a culture dish to peel off the RPE. The remaining neural retinas were homogenized by pipetting and cultured in T25 or T75 flasks (Falcon, Waltham, MA) for 7 days at $37^{\circ} \mathrm{C}$ in DMEM containing $1 \%$ penicillin/streptomycin and $20 \%$ fetal bovine serum (FBS; ThermoFisher). After 1 week, the culture medium was changed and the remaining adherent cells were left to replicate for another 7 to 10 days. The medium was changed every other day. After the last medium change, cells adherent to the plastic surface were treated with $0.05 \%$ trypsin (Invitrogen) for 2 to 3 minutes, and the less adhesive cells were collected as RMM. A small portion of RMM (approximately 25,000 cells) was plated on a $\mu$-slide (Ibidi, Fitchburg, WI) and kept overnight in DMEM containing $1 \%$ penicillin/streptomycin and 20\% FBS. These cells were used for the characterization of preparation homogeneity. The remaining RMMs were plated (no less than 250,000 cells per well) in 6-well tissue culture plates (Falcon) and allowed to adhere for 5 to 6 hours. Cells were then starved overnight in DMEM containing $1 \%$ penicillin/streptomycin without FBS; the next morning, they were stimulated for 6 hours with or without $100 \mathrm{ng} / \mathrm{mL}$ lipopolysaccharide (LPS; Escherichia coli O111:B4; InvivoGen, San Diego, CA). At the end of stimulation, cells were washed with ice-cold PBS and lysed with TRIzol reagent (ThermoFisher) for RNA isolation. The isolation of BMDM was as described. ${ }^{35}$ Briefly, bone marrows from femurs and tibias were incubated for 7 days in RPMI medium 1640 (ThermoFisher) containing 20\% FBS and 30\% L929-conditioned medium (obtained as described $^{36}$ ) to differentiate them into macrophages. Subsequent cell processing, characterization, and treatment were the same as for RMM. The RMM and BMDM homogeneity was $>90 \%$, as assessed by morphology and staining for ionized calcium binding adaptor molecule 1 (Iba1).

\section{Isolation and Treatment of HRECs, BRECs, and RPE}

Human retinal endothelial cell (HREC), bovine retinal endothelial cell (BREC), and RPE isolation and characterization were as described ${ }^{16,37}$ using donor retinas ${ }^{38}$ provided by the National Disease Research Interchange and eyes donated by the Michigan State University Meat Laboratory, respectively. Before treatment, BREC and RPE were serum starved in 1\% FBS complete medium. Cells were then treated with TNF- $\alpha$ (R\&D Systems, Minneapolis, MN), a diabetic relevant stimulus, for 24 hours $(10 \mathrm{ng} / \mathrm{mL})$ as described, ${ }^{39}$ followed by RNA isolation. 


\section{Quantitative Real-Time PCR}

Total RNA $(1 \mu \mathrm{g})$ from pooled samples of mouse retinas, RMM, and BMDM was isolated as described ${ }^{4}$ using the TRIzol Reagent (ThermoFisher). This RNA was then converted to cDNA by SuperScript III reverse transcriptase (Invitrogen), according to manufacturer's instructions. PCRs were performed in triplicate and were normalized to $\beta$-actin. The isolation of total RNA $(1 \mu \mathrm{g})$ from HREC, BREC, and RPE was as described ${ }^{16}$ using the RNeasy minikit (Qiagen, Valencia, CA). First-strand cDNA was synthesized using SuperScript II reverse transcription. All PCRs were performed in triplicate and normalized to cyclophilin A (CypA). The primer sequences are shown in Table 1. Changes in relative mRNA level were calculated by the $2^{-\Delta \Delta \mathrm{Ct}}$ method. ${ }^{40}$

\section{Histochemistry}

Retinal stains for unesterified cholesterol (UC) and esterified cholesterol (EC) were performed as described ${ }^{8}$ using filipin (Cayman Chemical, Ann Arbor, MI).

\section{Immunohistochemistry}

The preparation of frozen retinal sections was as described. ${ }^{10}$ Before the experiment, retinal sections were warmed to room temperature for 30 minutes and washed three times for 5 minutes with PBS containing $0.05 \%$ Tween 20 . Sections were then permeabilized for 20 minutes with PBS containing $0.5 \%$ Triton X-100 and blocked for 1 hour with 5\% normal goat serum (PCN5000; Invitrogen) in PBS containing 0.05\% Tween 20 (blocking buffer). Sections were incubated overnight at $4{ }^{\circ} \mathrm{C}$ with either rabbit anti-albumin antibodies (ab207327; Abcam, Cambridge, MA; 1:500 dilutions in blocking buffer) or blocking buffer. The next morning, slides were washed three times for 5 minutes with PBS containing $0.05 \%$ Tween 20 and incubated for 1 hour in the dark with either Alexa Fluor 647-conjugated goat anti-rabbit IgG (111-605-144; Jackson ImmunoResearch, West Grove, PA; 1:200 dilutions in blocking buffer) or blocking buffer. Sections were washed three times for 5 minutes with PBS, then dipped three times in distilled water, and next covered with ProLong Gold antifade reagent with DAPI (P36935; Molecular Probes, Eugene, OR) and protected with a glass coverslip. After image acquisition, a coverslip was removed, and sections were washed three times for 5 minutes with PBS, followed by staining at room temperature for 30 minutes with isolectin B4 (121413; Invitrogen; 1:100 dilutions in PBS). Slides were washed three times with PBS, then two times with distilled water, blotted dry, and mounted with ProLong Gold antifade reagent without DAPI (P36965; Molecular Probes).

Table 1 Primers for Quantitative Real-Time PCR

\begin{tabular}{|c|c|c|c|}
\hline Gene & Forward primer & Reverse primer & Species \\
\hline Abca1 & 5'-AGGCCGCACCATTATTTTGTC-3' & 5'-GGCAATTCTGTCCCCAAGGAT-3' & M \\
\hline$A b c g 1$ & 5'-АTTTCATCGTCCTGGGCATCT-3' & 5'-CGGATTTTGTATCTGAGGACGAA-3' & M \\
\hline $\operatorname{Act} \beta$ & $5^{\prime}-\mathrm{TGTTACCAACTGGGACGACATG-3^{ \prime }}$ & 5'-TTGTAGAAGGTGTGGTGCCAGA-3' & M \\
\hline Aim & $5^{\prime}$-CGTTAGAAGAAGAAGGTCGTTGGA-3' & $5^{\prime}$-AGATATGCAAGCGACCCATCTAC-3' & M \\
\hline Apod & $5^{\prime}-\mathrm{TGAAGCCAAACAGAGCAACGT-3^{ \prime }}$ & $5^{\prime}$-GGCATCAACGGGAAGAACTG-3' & M \\
\hline Apoe & $5^{\prime}-$ GGCCCAGGAGAATCAATGAG-3' & $5^{\prime}$-CCTGGCTGGATATGGATGTTG-3' & M \\
\hline $\operatorname{ArgII}$ & 5'-GACCACAGCCTGGCAATAGGT-3' & $5^{\prime}-\mathrm{TCAACCCAGATGACACAGAGATCT-} 3^{\prime}$ & M \\
\hline $\mathrm{Ccl} 2$ & 5'-TCACTGAAGCCAGCTCTCTCTTC-3' & $5^{\prime}-$ GTGAACAGCAGGCCCAGAA- $3^{\prime}$ & M \\
\hline Cox-2 & 5'-CACCTCAAGAACATCCAGAGCTT-3' & 5'-CTCGCGACCATTCTTGAGTGT-3' & M \\
\hline Cxcl1 & 5'-CACCTCAAGAACATCCAGAGCTT-3' & 5'-CTCGCGACCATTCTTGAGTGT-3' & M \\
\hline CYPA & $5^{\prime}-$ GGTCCCAAAGACAGCAGAAA-3' & $5^{\prime}-$ GTCACCACCGTCACACATAAA-3' & $\mathrm{H}$ \\
\hline СурА & 5'-GAGCACTGGAGAGAAAGGATTT-3' & 5'-GACTTGCCACCAGTACCATTAT-3' & $\mathrm{B}$ \\
\hline CYP27A1 & $5^{\prime}-\mathrm{CACAAACTCCCGGATCATAGAA-3^{ \prime }}$ & $5^{\prime}-$ CACATAGTGGAACACAAAC- $3^{\prime}$ & $\mathrm{H}$ \\
\hline Cyp27a1 & $5^{\prime}-\mathrm{AGTAGACACGACATCCAACAC-3^{ \prime }}$ & 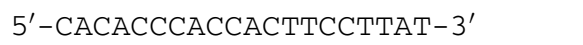 & $\mathrm{B}$ \\
\hline CYP46A1 & 5'-GAGTCCTGAGTCGCTTAAGAAG-3' & $5^{\prime}$-CGAAGAGTCTCTCACCAAACA-3' & $\mathrm{H}$ \\
\hline Cyp46a1 & 5'-CAAGCCCAAGTTCACCTACT-3' & $5^{\prime}-$ TCACCTCCATCTGAGCAAAC-3' & B \\
\hline Glut4 & $5^{\prime}-\mathrm{ACCGGATTCCATCCCACAA-3^{ \prime }}$ & $5^{\prime}-$ CATGCCACCCACAGAGAAGA-3' & M \\
\hline Idol & $5^{\prime}$-GGAGCATGTCCAGCACGTCTA-3' & $5^{\prime}$-GTGCAGGACGCATCAGATGA-3' & M \\
\hline Il-1 $\beta$ & $5^{\prime}$-GGTCAAAGGTTTGGAAGCAG-3' & 5'-TGTGAAATGCCACCTTTTGA-3' & M \\
\hline Il-6 & $5^{\prime}$-AGTTGCCTTCTTGGGACTGA-3' & $5^{\prime}-\mathrm{TCCACGATTTCCCAGAGAAC}-3^{\prime}$ & M \\
\hline iNOS & $5^{\prime}-$ GCCACCAACAATGGCAACA-3' & $5^{\prime}-$ CGTACCGGATGAGCTGTGAA-3' & M \\
\hline$L x r \alpha$ & $5^{\prime}-$ AGCGTCCATTCAGAGCAAGTG-3' & $5^{\prime}$-CACTCGTGGACATCCCAGATCT-3' & M \\
\hline $\operatorname{Lxr} \beta$ & 5'-ACTCGGAGCAGGTCTTTGCAT-3' & $5^{\prime}$-CCTACTCGTGCACATCCCAGAT-3' & M \\
\hline Mertk & $5^{\prime}-$ AAAGGTCCCCGTCTGTCCTAA-3' & $5^{\prime}-$ TGGACACCGTCAGTCCTTTGT-3' & M \\
\hline Srebp1a & $5^{\prime}-$ ATGGACGAGCCACCCTTCA-3' & $5^{\prime}-$ AAGTCACTGTCTTGGTTGTTGATGA-3' & M \\
\hline Srebp1c & $5^{\prime}-\mathrm{ACGGAGCCATGGATTGCA}-3^{\prime}$ & $5^{\prime}$-AAGTCACTGTCTTGGTTGTTGATGA-3' & M \\
\hline $\operatorname{Tnf} \alpha$ & $5^{\prime}$-GGTCTGGGCCATAGAACTGA-3' & 5'-CAGCСTCTTCTCATTССТGC-3' & M \\
\hline
\end{tabular}

$B$, bulls; $H$, humans; $M$, mice. 
Staining of retinal cross sections for CYP46A1, CD31, and neuronal-specific nuclear protein was conducted similarly using the following sources and dilutions of primary and secondary antibodies: polyclonal rabbit anti-CYP46A1 IgG $\left(\mathrm{OD}_{280}=0.6 ; 1: 200\right.$ dilutions; generated in the laboratory of I.A.P.) and donkey anti-rabbit AF 488 antibody (A21206; Invitrogen; 1:500 dilution); monoclonal mouse CD31 antibody (sc-81158; Santa Cruz Biotechnology, Dallas, TX; 1:100 dilution); donkey anti-mouse AF 555 antibody (A31570; Invitrogen; 1:500 dilution); monoclonal mouse neuronalspecific nuclear protein antibody (MAB377; Millipore Sigma, St. Louis, MO; 1:100 dilution); and donkey anti-mouse AF 555 antibody (A31570; Invitrogen; 1:500 dilution).

The anti-Ibal staining of RMM and BMDM was performed after cell medium was discarded and cells were washed with ice-cold PBS. Cells were then fixed for 15 to 20 minutes in $4 \%$ paraformaldehyde, washed three times with PBS containing $0.05 \%$ Tween 20 , and treated with rabbit anti-Ibal antibodies (019-19741; Wako, Richmond, VA; 1:1000 dilutions), followed by the incubation with Alexa Fluor 647-conjugated goat anti-rabbit IgG (4414; Cell Signaling, Danvers, MA; 1:200 dilution), as described above for retinal sections.

The preparation of retinal flat mounts was as described. ${ }^{41}$ Briefly, mice were sacrificed and their eyes were enucleated, followed by fixation in $4 \%$ paraformaldehyde for 15 minutes at room temperature (for $\mathrm{F} 4 / 80$ staining) or 4 hours at $4^{\circ} \mathrm{C}$ (for CYP46A1 and CD31 staining). Eyes were then washed three times with PBS and stored in PBS until processing for flat mounts, which included the cornea, lens, and vitreous removal, and four incisions from outside of the eye cup toward the center. Next, retinal flat mounts were permeabilized and blocked for 24 hours at $4^{\circ} \mathrm{C}$ with PBS containing $0.5 \%$ Triton $\mathrm{X}-100,5 \%$ bovine serum albumin, and either 5\% normal goat serum (for F4/80 staining) or 2\% donkey serum (for CYP46A1 and CD31 staining). Subsequent incubation with primary rat antibodies against F4/80 (MCA497GA; AbD Serotec, now BioRad, Hercules, CA; 1:100 dilutions in PBS) was overnight at $4^{\circ} \mathrm{C}$, followed by a 6-hour incubation at $4^{\circ} \mathrm{C}$ with Hoechst (33342; Invitrogen; $1: 1000$ dilutions in PBS). The incubation with the polyclonal rabbit anti-CYP46A1 $\operatorname{IgG}\left(\mathrm{OD}_{280}=0.6 ; 1: 200\right.$ dilutions; generated in the laboratory of I.A.P.) and monoclonal mouse CD31 antibodies (sc-81158; Santa Cruz Biotechnology; 1:100 dilutions in PBS) was for 24 hours at $4^{\circ} \mathrm{C}$. Retinal flat mounts were then washed for 1 hour at $4^{\circ} \mathrm{C}$ with four changes of PBS and incubated for 1 hour at room temperature in $2 \%$ bovine serum albumin, followed by an overnight incubation at $4{ }^{\circ} \mathrm{C}$ in PBS. The next morning, either anti-rat Alexa 647 IgG (4418; Cell Signaling, Danvers, MA; 1:200 dilutions) was added (for F4/80 staining) or donkey anti-rabbit AF 488 and donkey anti-mouse AF 555 (A21206 and A31570, respectively; Invitrogen; 1:500 dilutions) were added (for CYP46A1 and CD31 staining, respectively) and incubated for 24 hours at $4^{\circ} \mathrm{C}$. Retinal flat mounts were washed for 1 hour at $4^{\circ} \mathrm{C}$ with four changes of PBS and then mounted with either ProLong Gold without DAPI (for F4/80 staining) or VECTASHIELD mounting media with DAPI (H-1200; Vector Laboratories, Inc., Burlingame, CA) (for CYP46A1 and CD31 staining). The F4/80 staining was imaged on an inverted microscope (DMI 6000 B; Leica Microsystems, Buffalo Grove, IL) using a Retiga EXi-Fast camera (QImaging, Surrey, BC, Canada), and the CYP46A1 and CD32 staining was imaged on a Nikon Eclipse Ti with C2+ confocal system (Nikon Instruments Inc., Melville, NY).

\section{Retinal Phosphoproteomics}

Retinal processing was the same as for the brain ${ }^{42}$ and used three Cyp46a1 ${ }^{-/-}$and three Cyp46a1 ${ }^{+/+}$samples, each containing two retinas from the same animal, an 8- to 10month-old female mouse. All chemicals were from SigmaAldrich (St. Louis, MO) unless otherwise indicated. Briefly, each sample was lysed in $0.5 \mathrm{~mL}$ of $20 \mathrm{mmol} / \mathrm{L}$ HEPES buffer, $\mathrm{pH} 8.0$, containing $9 \mathrm{~mol} / \mathrm{L}$ urea and $1 \times$ Halt phosphatase inhibitor cocktail (ThermoFisher Scientific, Waltham, MA) and alkylated with $30 \mathrm{mmol} / \mathrm{L}$ iodoacetamide after reduction with $10 \mathrm{mmol} / \mathrm{L}$ dithiothreitol. A total of $0.25 \mathrm{mg}$ of protein from each sample was digested with trypsin and subjected to phosphoserine and phosphothreonine enrichment using the ThermoFisher Scientific Pierce $\mathrm{TiO}_{2}$ Phosphopeptide Enrichment and Clean-up Kit. Enriched peptide samples were subjected to cleanup by $\mathrm{C} 18$ cartridges (Waters Corp., Milford, MA) and were analyzed by a Finnigan LTQ-Obitrap Elite hybrid mass spectrometer (ThermoFisher Scientific) connected to a Dionex Acclaim Pepmap C18 reversed-phase capillary chromatography column (ThermoFisher Scientific). All collision-induced dissociation spectra obtained were searched for the mouse reference sequence using Sequest that is bundled in Proteome Discoverer 1.4 (ThermoFisher Scientific); oxidized methionine, along with the serine, threonine, and tyrosine phosphorylation, was considered as a dynamic modification. Carbamidomethylation of cysteine residues was considered as a static modification. The resulting search results were filtered on the basis of Sequest XCorr scores $>1.5(+1), 2.0(+2), 2.25(+3)$, and 2.5 $(+4)$. The quantitation of the phosphorylated peptides was by a label-free method, which involves aligning the liquid chromatography runs and comparing the extracted ion chromatograms for each identified peptide by SIEVE (ThermoFisher Scientific). Data were normalized to the total ion chromatogram. All differentially expressed phosphopeptides were manually validated using a second normalization step to the synthetic phosphopeptides added as internal standards. Differentially abundant phosphorylated proteins in the Cyp46al ${ }^{-1-}$ retina were analyzed manually using Molecular function and Biological process annotations of UniProt (http://www.uniprot.org, last accessed July 12, 2018).

\section{Statistical Analysis}

The quantitative data represent either the means \pm SEM or the means $\pm \mathrm{SD}$; the number of animals $(n)$ is indicated in each 
figure or figure legend. All images are representative of studies in three to five animals per genotype. Data were analyzed by either a two-tailed, unpaired $t$-test or the two-way analysis of variance with Bonferroni correction. $P \leq 0.05$ was considered statistically significant.

\section{Results}

\section{Retinal and Serum Lipids in Cyp46a1 ${ }^{-/-}$Mice}

Retinal samples for sterol quantifications were composed of both the neural retina and RPE. Total retinal cholesterol (a sum of UC and EC) was increased 1.7- and 1.8-fold in male and female Cyp46a1 ${ }^{-1-}$ mice, respectively, whereas UC either remained unchanged (Cyp46al ${ }^{-1-}$ female mice) or was reduced 1.2-fold (Cyp46al ${ }^{-1-}$ male mice) (Figure 1A), suggesting that cholesterol excess in the Cyp46al ${ }^{-/-}$genotype was converted to EC, as was previously observed in the

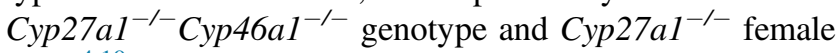
mice. ${ }^{4,10}$ In addition, a lack of metabolic ability of the Cyp46a1 ${ }^{-/-}$retina to convert cholesterol to $24 \mathrm{HC}$ led to a compensatory increase in retinal cholesterol elimination via 27-hydroxylation by CYP27A1. However, 27HC was not detected in the $\mathrm{Cyp}_{46 \mathrm{al}} \mathrm{I}^{-1}$ retina; instead, there was a 3.5fold increase in 5-cholestenoic acid $(27 \mathrm{COOH})$, a metabolic product generated from 27HC by CYP27A1 (Figure 1B). Retinal cholesterol biosynthesis was affected only slightly in both neurons and astrocytes of Cyp46al ${ }^{-/-}$mice, as indicated by the levels of cholesterol precursors lathosterol and desmosterol, respectively. Yet, a 1.5-fold reduction of lathosterol was observed in $\mathrm{Cyp}_{46 \mathrm{al}} \mathrm{I}^{--}$male mice (Figure 1C). Serum lipids were mostly unchanged in Cyp46a1 ${ }^{-1-}$ mice, except a 1.8-fold increase in low-density lipoprotein cholesterol, whose fraction in mice is small compared with high-density lipoprotein cholesterol (Figure 1D). Collectively, these data support that changes in total cholesterol in the Cyp46a1 ${ }^{-/-}$retina reflect disturbances in local retinal cholesterol homeostasis rather than in systemic lipids.

Retinal distribution of UC and EC in Cyp46a1 ${ }^{-1-}$ mice was investigated by staining of retinal cross sections with a fluorescent compound filipin. The staining pattern for UC was similar in wild-type and Cyp46a1 ${ }^{-/-}$mice (Figure 2); the only difference was a diffuse filipin fluorescence observed within the RPE layer in Cyp46a1 $1^{-/}$animals. EC was not detectable in the retina of wild-type mice (Figure 2), whereas in Cyp46a1 ${ }^{-1-}$ mice, it was mainly localized to the photoreceptors and basal membrane of the RPE (Figure 2). Compared with the Cyp27al ${ }^{-/}$Cyp $46 a 1^{-/-}$retina, ${ }^{43}$ there was an additional accumulation of EC in the inner segments of Cyp46a1 ${ }^{-1-}$ mice. Conversely, the inner Cyp46a1 retina had only a faint filipin fluorescence for EC.

\section{Overall Retinal Function in Cyp46a1 ${ }^{-/-}$Mice}

ERGs were recorded under dark- and light-adapted conditions from female and male mice (Figure 3). Neither darkadapted (scotopic) ERGs nor light-adapted (photopic) ERGs of Cyp46a1 ${ }^{-1-}$ mice were significantly different from those of $\mathrm{Cyp} 4 \mathrm{al}^{+/+}$mice. This is different from

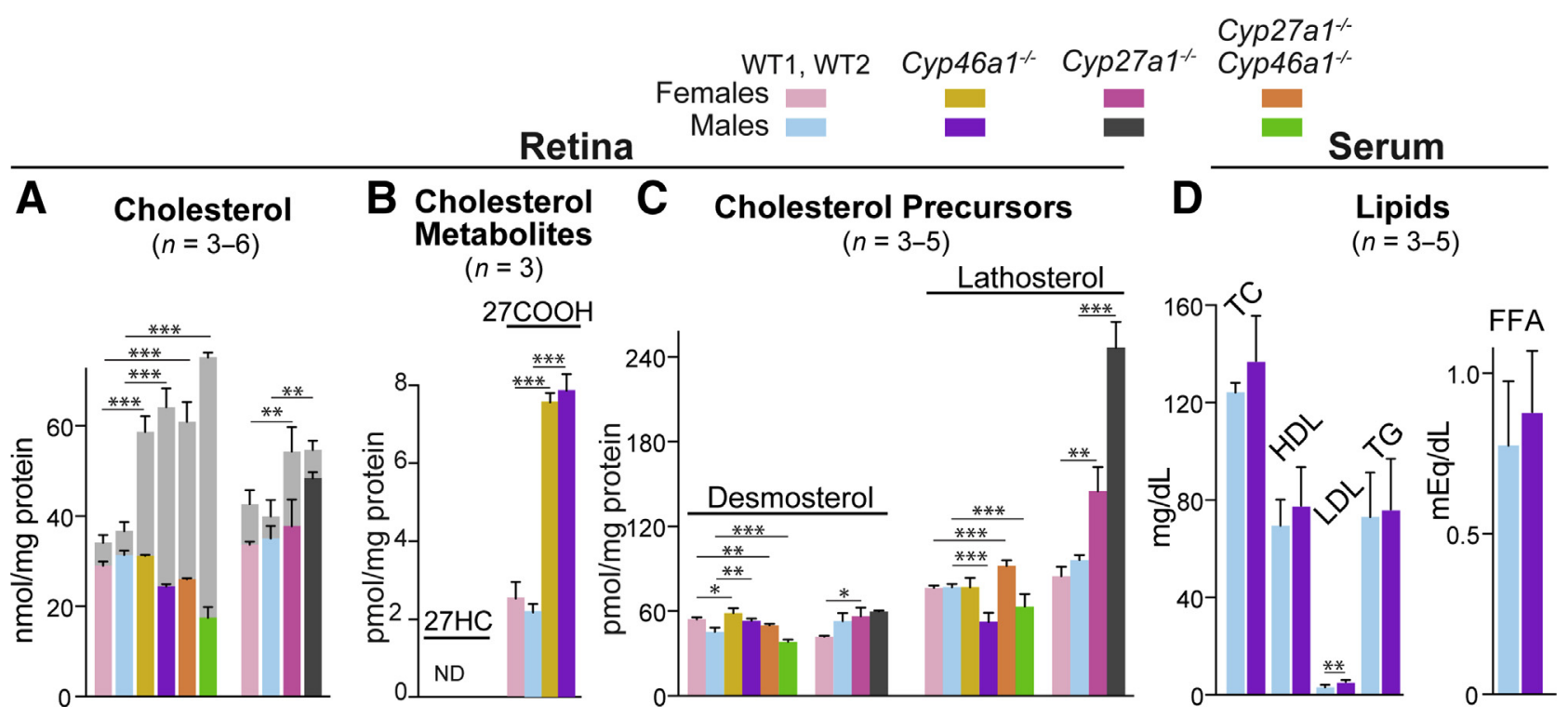

Figure 1 Retinal and serum lipids in mice of different genotypes. A-C: Colored bars indicate unesterified sterols in female and male mice of different genotypes; gray bars indicate esterified cholesterol in animals of both sexes. D: Blue and ink bars indicate serum lipids in wild-type (WT) and Cyp46a1 ${ }^{-/-}$male mice. The results are the measurements in samples from individual animals $(n)$, whose number is indicated in parenthesis on each panel. Only 5-cholestenoic acid $(27 \mathrm{COOH})$ was measured in pooled samples of 8 to 10 retinas from four to five mice; the results are triplicate measurements. Cyp46a1 ${ }^{-/-}$and Cyp27a1 ${ }^{-/}$Cyp46a1 ${ }^{-/}$mice were on a background (C57BL/6J;129S6/SvEv) different from that of Cyp27a1 ${ }^{-1-}$ mice (C57BL/6J); hence, sterols were measured in WT animals on two different backgrounds, WT1 and WT2. Data are expressed as means \pm SD. ${ }^{*} P \leq 0.05,{ }^{* *} P \leq 0.01$, and ${ }^{* * *} P \leq 0.001$ versus WT mice of the same sex (two-tailed, unpaired $t$-test). FFA, free fatty acid; HDL, high-density lipoprotein, LDL, low-density lipoprotein; ND, not determined; 27-0H, 27-hydroxycholesterol; TC, total cholesterol; TG, triglyceride. 

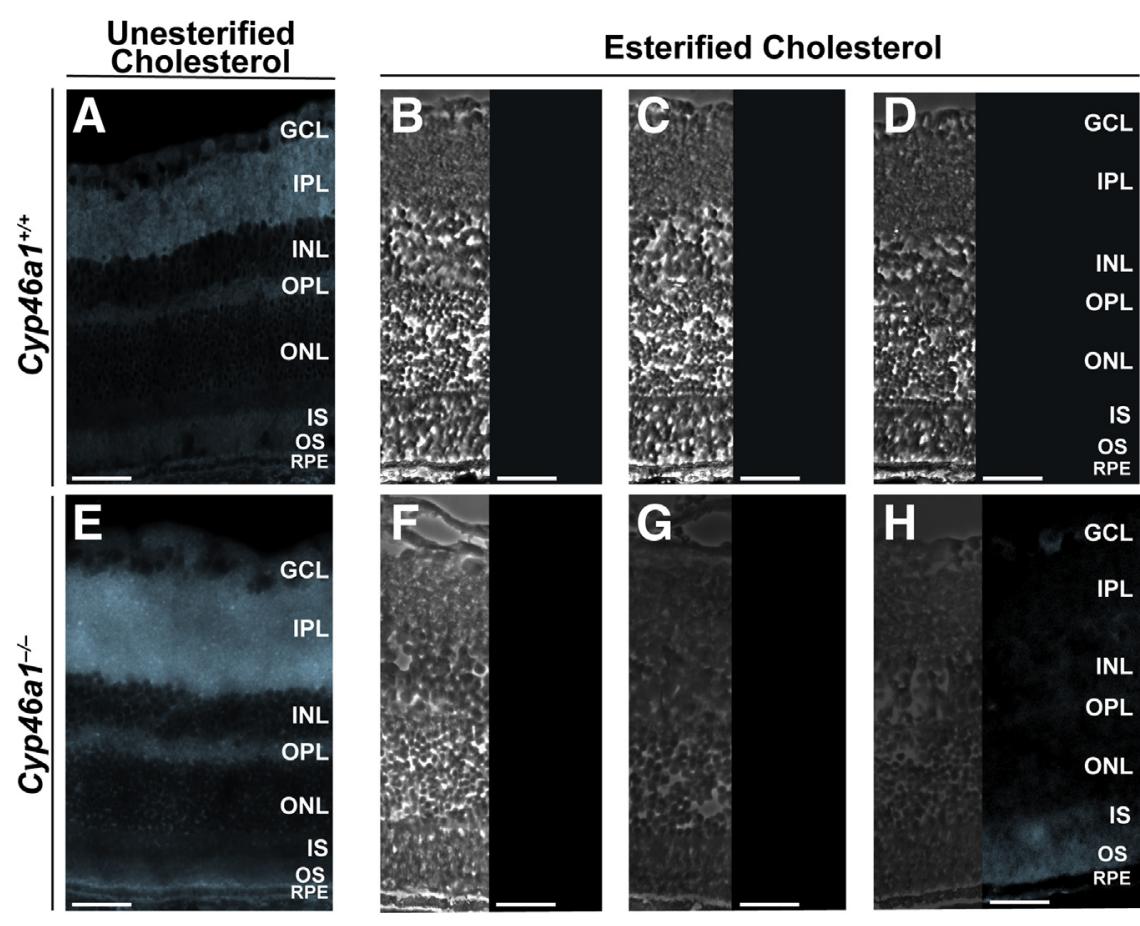

Figure 2 Retinal detection of unesterified and esterified cholesterol with filipin. Representative images are shown. A and E: Stains (cyan) for unesterified cholesterol (these sections were treated with filipin). B and F: Control stains for completeness of removal of unesterified cholesterol (these sections were extracted with $70 \%$ aqueous ethanol and treated then with filipin). C and G: Control stains for background fluorescence (these sections were extracted with ethanol but not treated with filipin). D and H: Stains (cyan) for esterified cholesterol (these sections were extracted with $70 \%$ ethanol and then sequentially treated with cholesterol esterase and filipin). B-D and $\mathbf{F}-\mathbf{H}$ : Panels for esterified cholesterol consist of phase contrast images (left panels) and histochemistry images (right panels). $n=3(\mathbf{A}-\mathbf{H})$. Scale bars $=50 \mu \mathrm{m}(\mathbf{A}-\mathbf{H})$. GCL, ganglion cell layer; INL, inner nuclear layer; IPL, inner plexiform layer; IS, photoreceptor inner segment; $0 \mathrm{NL}$, outer nuclear layer; $\mathrm{OPL}$, outer plexiform layer; $\mathrm{OS}$, photoreceptor outer segment; RPE, retinal pigment epithelium.

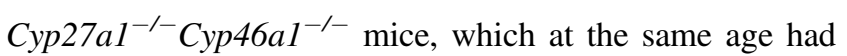
sex-specific amplitude reductions in both scotopic and photopic ERGs. ${ }^{43}$

\section{Retinal Vasculature in Cyp46a1 ${ }^{-/-}$Mice}

The retinal vasculature was evaluated using FA, an in vivo imaging technique. The beam of the laser scanning ophthalmoscope was focused on the superficial/intermediate plexi of the retinal vasculature to detect retinal capillaries, and fundus images were acquired during early, intermediate, and late phases of FA (Figure 4A). Initial assessments were conducted on 6-week-old mice, and no vascular abnormalities were detected (data not shown). However, when mice were reevaluated at 6 months of age or later, retinal venous beading and tortuosity, typical features of diabetic retinopathy in humans, were observed. ${ }^{1,3}$ In addition, bright fluorescent spots were seen, which were particularly visible

\section{Electroretinography Responses}

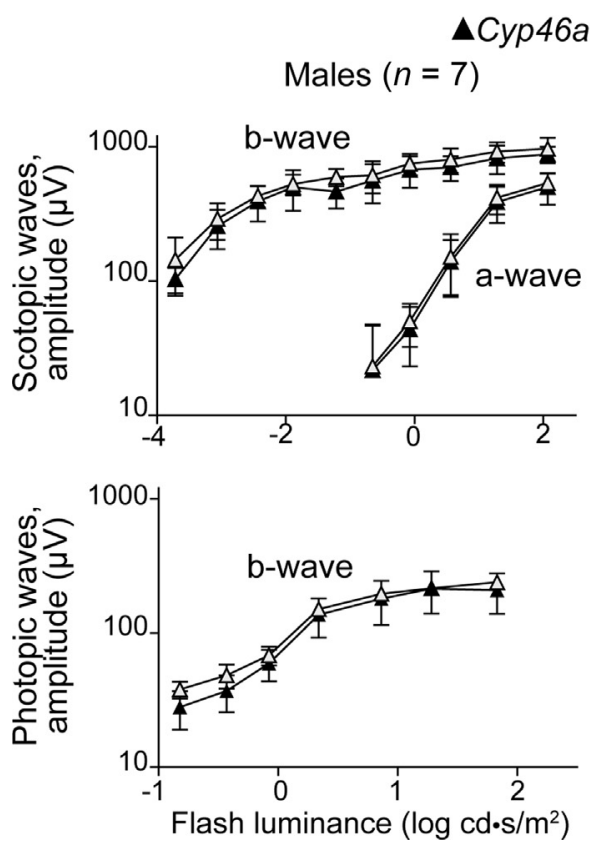

\section{$\triangle$ Cyp46a1-1-}
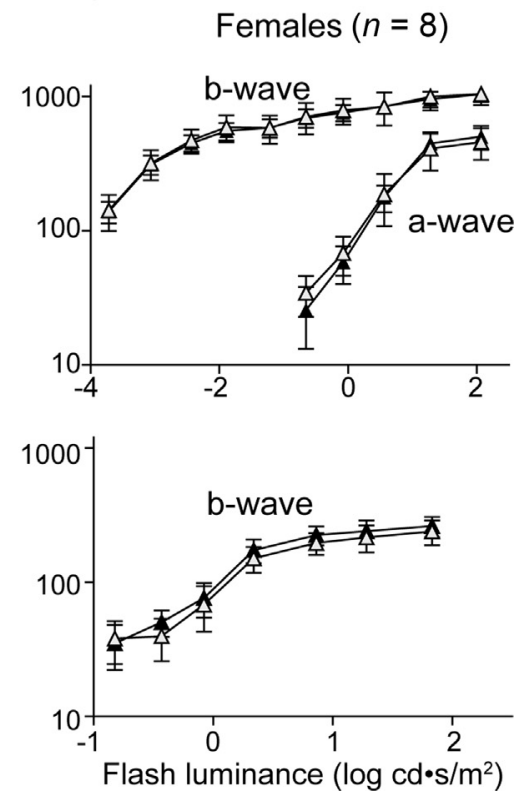

Figure 3 Electroretinography responses in 6 month-old Cyp46a1 ${ }^{-/-}$mice. The results are the measurements in seven male and eight female mice. Analysis of variance with repeated measures was used for statistical analysis, and no significant changes $(P \leq 0.05)$ were found in Cyp46a1-/mice compared with Cyp46a1 $1^{+/+}$mice. Data are expressed as means \pm SEM. 
during intermediate and late FA stages; the appearance of these spots was similar to that of capillary microaneuryms. Furthermore, diffuse margins of retinal capillaries during intermediate and late FA stages were indicative of a marked increase in vascular permeability. All of the observed abnormalities were present in the Cyp27al ${ }^{-1}{ }^{-}$Cyp $46 a 1^{-1}$ retina ${ }^{43}$ but in $C y p 46 a 1^{-1-}$ mice, these abnormalities were less prominent than in the double-knockout animals.

Increased vasopermeability in the Cyp46al ${ }^{-/-}$retina was further confirmed by staining for albumin, normally remaining restricted within blood vessels. ${ }^{44}$ Yet, retinal vessels become permeable to small molecules in diabetic retinopathy, thus enabling lipids and proteins, such as albumin, to leak into surrounding tissues. ${ }^{44}$ Albumin extravasation from both large and small blood vessels was detected in the Cyp46al ${ }^{-1-}$ retina, stained also with isolectin B4 to delineate blood vessels (Figure 4B). By contrast, the $C y p 46 a^{+/+}$retina had the anti-albumin immunoreactivity only within the large blood vessels of the ganglion cell layer with no detectable albumin staining in the inner nuclear layer and outer plexiform layer containing retinal capillaries.

\section{Serum Glucose and Glucose Tolerance in Cyp46a1-/- Mice}

The fasting blood glucose levels were slightly decreased in Cyp46a1 ${ }^{-1-}$ mice compared with Cyp46a1 $1^{+/+}$mice (Figure 5A). However, during a glucose tolerance test, the sugar levels were always higher in Cyp46al ${ }^{-1-}$ mice (Figure 5B), even 150 minutes after injection, the time when in wild-type mice, serum glucose returned to the preinjection level (Figure 5B). Thus, the Cyp46a1 ${ }^{-/-}$genotype seems to have delayed clearance of glucose.

\section{Retinal Gene Expression in Cyp46a1 ${ }^{-/-}$Mice}

Mainly LXRs and their target genes were evaluated. The expression of $L x r \alpha$ and $L x r \beta$ was significantly up-regulated (up to sevenfold) in the Cyp46al ${ }^{-1-}$ retina compared with the wild-type retina (Figure 6). Nevertheless, there was a substantial up-regulation of only one $(A b c g l)$ of the seven tested genes, which are normally transactivated by LXRs (Figure 6). The expression of the other transactivated targets was either unchanged (Abcal, ArgII, and Mertk) or slightly decreased (Apoe, Glut4, and Srebpc1, up to 1.2-fold) in the Cyp $46 a 1^{-1-}$ retina. Conversely, the expression of the genes that are normally suppressed by LXR activation via the inhibition of NF-кB (Ccl2, Cox2, Cxcll, iNos, and Tnfa) was mostly increased in the Cyp46a1 ${ }^{-1-}$ retina compared with the wild-type retina (up to 4.6-fold) (Figure 6). Thus, a lack of $24 \mathrm{HC}$ and increased $L x r$ expression in the Cyp $46 \mathrm{al}^{-1-}$ retina did not seem to affect the LXR transactivating activities but decreased the LXR transrepressing activities and thereby up-regulated the expression of key proinflammatory genes. The latter is consistent with the marked increase in vascular permeability observed in the Cyp46a1 ${ }^{-1-}$ retina (Figure 4B).

$\mathrm{NF}-\kappa \mathrm{B}$ regulates the expression of not only proinflammatory genes (Figure 6) but also of many other genes, including Srebpla, a potent activator of all SREBPresponsive genes, ${ }^{45}$ and of Nlrpla, which encodes a core
A Fluorescein Angiography, Phases

B
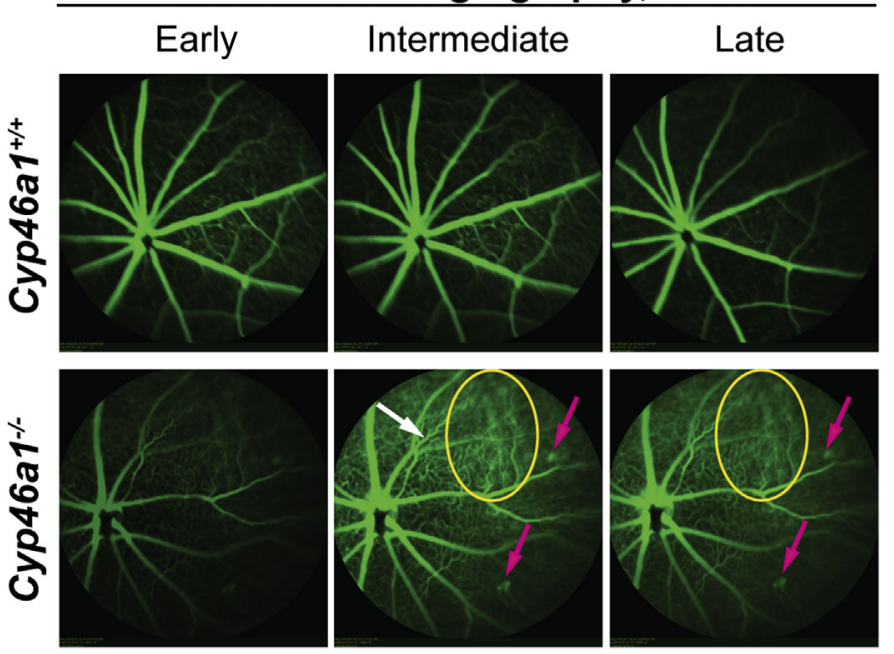

\section{Immunohistochemistry}

$\mathrm{NI} \quad 2^{\circ}$ Albumin Isolectin B4

\section{Merge}
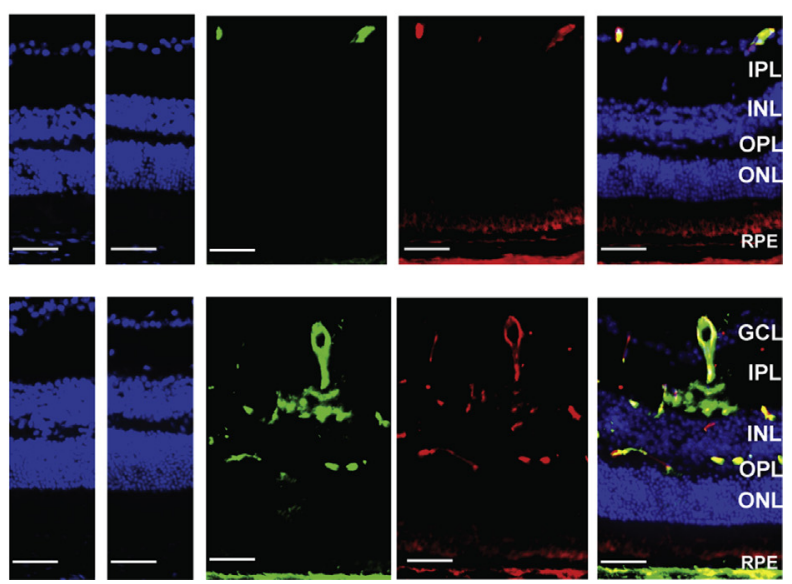

Figure 4 Vascular abnormalities and vascular leakage in the Cyp46a1 ${ }^{-/-}$retina, as assessed by fluorescein angiography and immunohistochemistry. A: Representative images of blood vessel tortuosity (white arrow), microaneurysm-like fluorescent spots (pink arrows), and area of vascular leakage (yellow ovals). B: Representative images of increased vascular permeability, as assessed by stains for albumin (green) and isolectin B4 (red). Nuclei were stained with DAPI (blue). $n=3$ (A and B). Scale bars $=50 \mu \mathrm{m}(\mathbf{B}) .2^{\circ}$, Control stain using secondary antibody only; GCL, ganglion cell layer; INL, inner nuclear layer; IPL, inner plexiform layer; IS, photoreceptor inner segment; NI, control stain using nonimmune serum; ONL, outer nuclear layer; $0 \mathrm{PL}$, outer plexiform layer; $0 \mathrm{~S}$, photoreceptor outer segment; RPE, retinal pigment epithelium. 


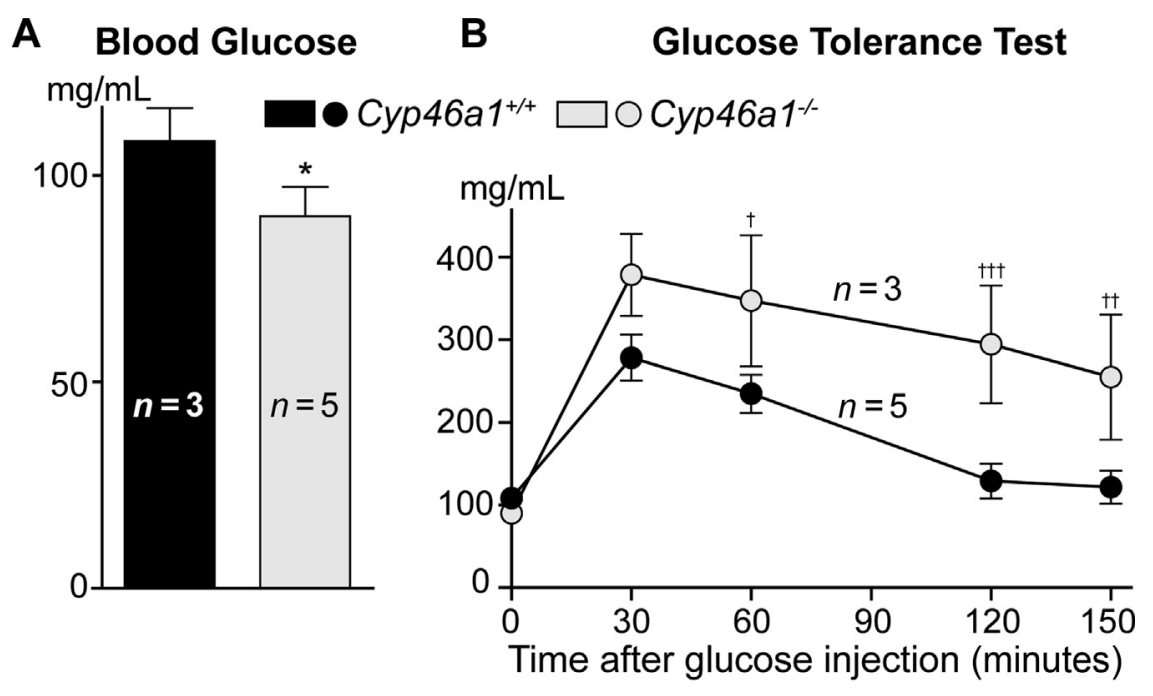

Figure 5 Fasting blood glucose and glucose tolerance test in Cyp46a1 ${ }^{-1}$ mice. The results are the measurements in samples from individual animals $(n)$, whose number is indicated on each panel. Data are expressed as means \pm SEM (A and $\mathbf{B}$ ). ${ }^{*} P \leq 0.05$ versus Cyp46a1 ${ }^{+/+}$mice (two-tailed, unpaired $t$-test); ${ }^{\dagger} P \leq 0.05,{ }^{\dagger} P \leq 0.01$, and ${ }^{\dagger \dagger} P \leq 0.001$ versus Cyp46a1 ${ }^{+/+}$mice (two-way analysis of variance, followed by the Bonferroni correction).

inflammasome component. ${ }^{46}$ The expression of Srebpla was increased only 1.25 -fold in the Cyp46a1 ${ }^{-/-}$retina (Figure 6), suggesting that retinal inflammasome complex as well as retinal expression of the canonical SREBP target genes (the pathways of cholesterol and fatty acid synthesis) were not significantly affected by a lack of 24HC.

\section{Basal Gene Expression in Macrophages}

The up-regulated expression in the Cyp46a1 ${ }^{-/-}$retina of some of the inflammatory genes prompted studies of the gene expression in RMM, innate immune cells either known (microglia) or suggested (macrophages from infiltrating monocytes) to be activated in diabetes in both humans and animal models. ${ }^{47-50}$ Macrophages are the most studied cells with respect to the LXR actions on immunity and were the first cell types in which the anti-inflammatory effects of LXRs were recognized. ${ }^{28,51}$ To ascertain whether retinal environment and knockout genotypes have specific effects on the gene expression in microglia/macrophages, both RMM and BMDM from five genetic lines were evaluated: two wild-type strains (C57BL/6J and C57BL/6J;129S6/ $\mathrm{SvEv})$ and three knockout genotypes $\left(\mathrm{Cyp} 46 \mathrm{al}^{-1-}\right.$, Cyp27a1 ${ }^{-/-}$, and Cyp27a1 ${ }^{-/-}{\text {Cyp } 46 a 1^{-1-}}^{-}$(Figure 7).

\section{Lxrs}

In the Cyp46al ${ }^{-1-}$ genotype, RMM exhibited increased Lxr $\alpha$ and $L x r \beta$ expression (3.6- and 3.4-fold, respectively). A lower (1.3-fold, $L x r \alpha)$ or unchanged gene expression $(L x r \beta)$ was found in the RMM from the Cyp27al ${ }^{-1-}$ genotype (Figure 7A). Accordingly, in the Cyp27al ${ }^{-/-}$ Cyp46a1 ${ }^{-/-}$RMM, the $L x r$ expression was increased 1.5-fold for $L x r \alpha$ and 1.4-fold for $L x r \beta$, representing a smaller increase

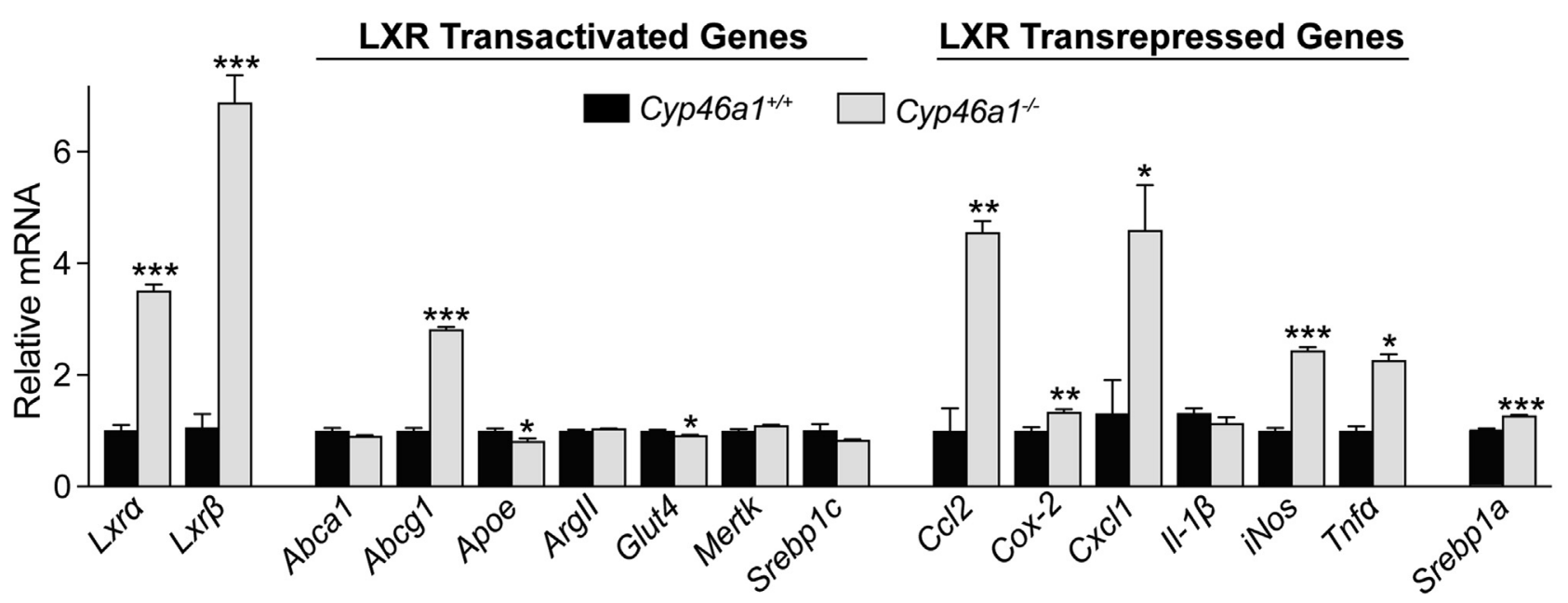

Figure 6 Retinal expression of Lxrs and LXR target genes in the Cyp46a ${ }^{-/-}$retina. The results are triplicate measurements in a pooled sample of 8 to 10 retinas from four to five mice. Data are expressed as means \pm SEM. ${ }^{*} P \leq 0.05,{ }^{*} P \leq 0.01$, and ${ }^{* * *} P \leq 0.001$ versus the Cyp46a1 ${ }^{+/+}$retina (two-tailed, unpaired $t$-test). 


\section{Retinal Microglia/Macrophages}

A

B

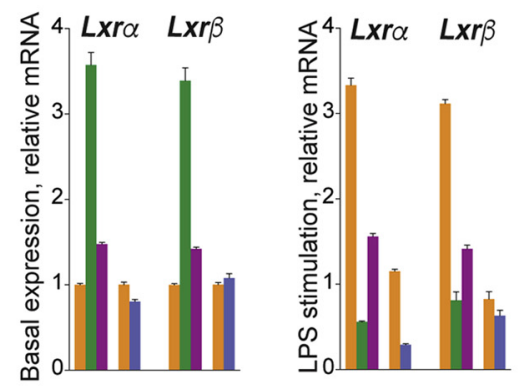

E

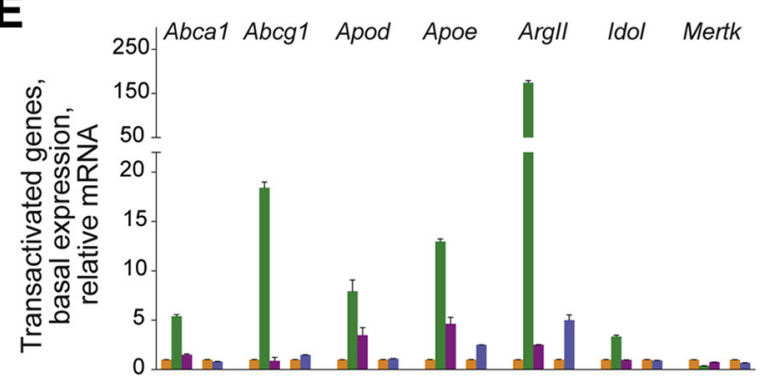

G

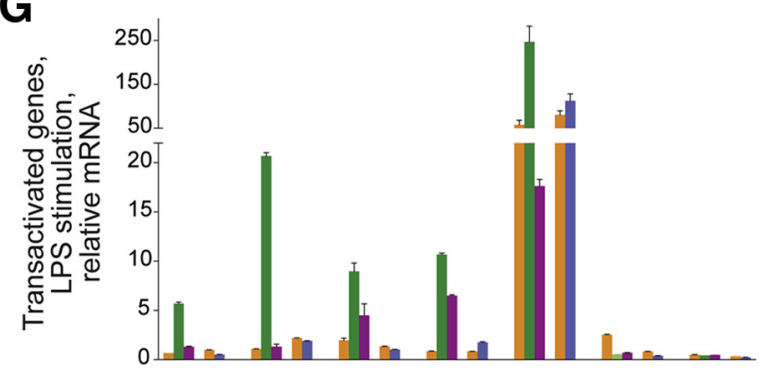

I

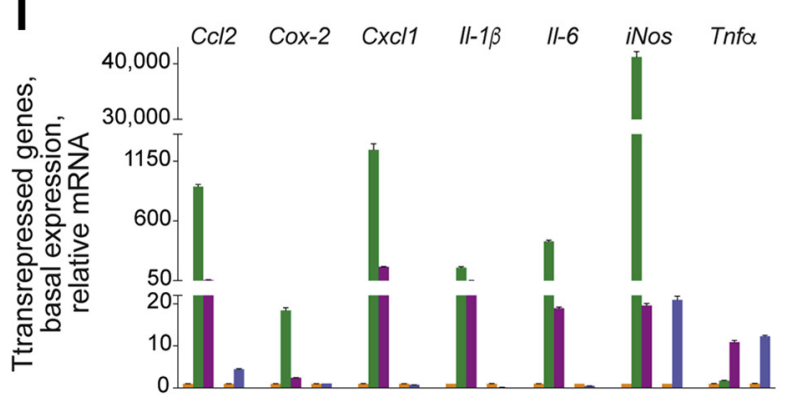

K

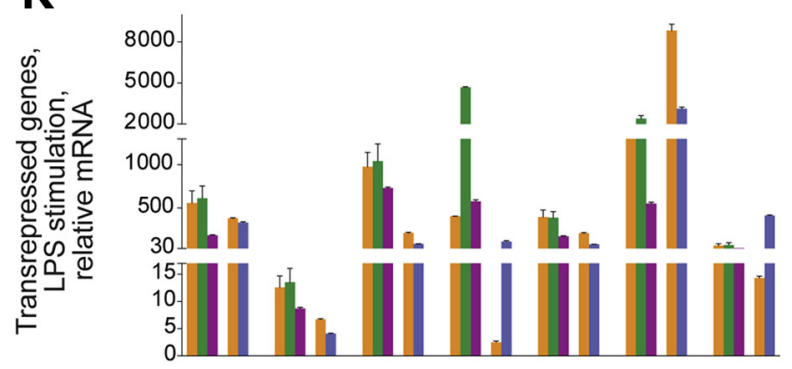

Bone Marrow-Derived Macrophages

C

D
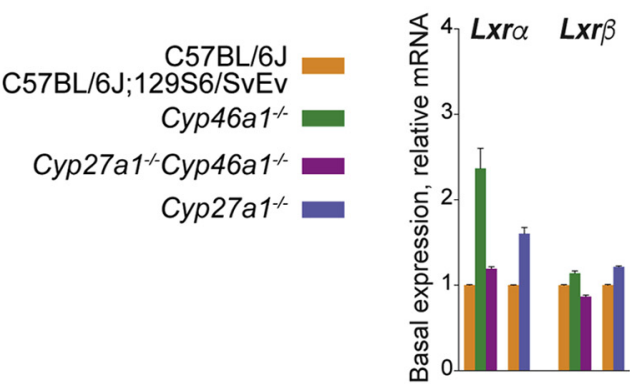

F 4 Abca1 abco1 Apod Apoe

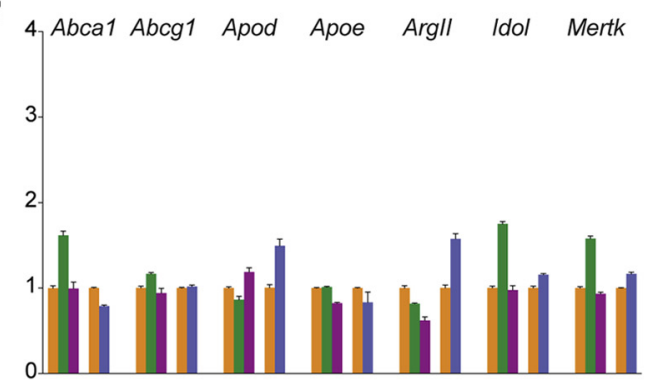

$\mathrm{H}_{4}$

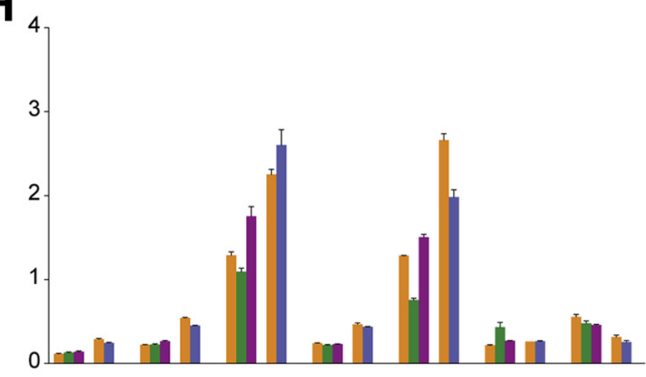

$\mathbf{J}$

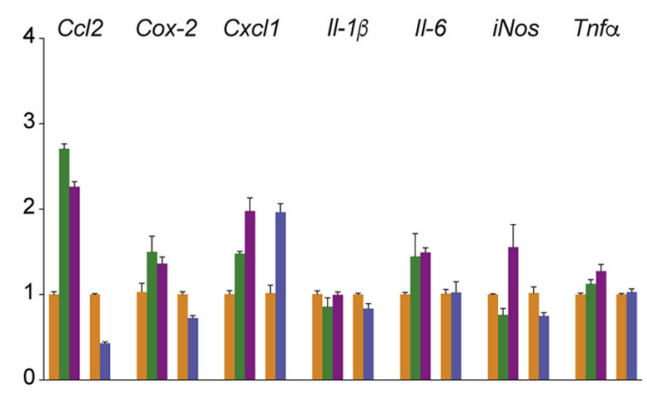

L

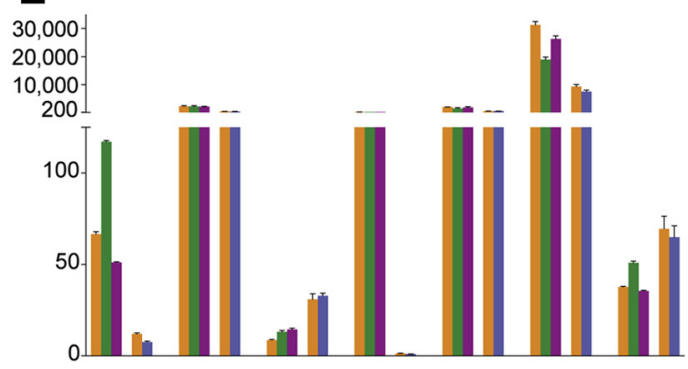

Figure 7 Expression of $L x r s$ and LXR target genes in mice of different genotypes. A, B, E, G, I, and K: Retinal microglia/macrophages. C, D, F, H, J, and L: Bone marrow-derived macrophages. The results are duplicate measurements in two to three different cell preparations. A, C, E, F, I, and J: Nonstimulated cells. B, D, G, H, K, and L: LPS-stimulated cells. A two-tailed, unpaired $t$-test was used to assess statistical significance in knockout genotypes relative to the corresponding wild-type cells; LPS-stimulated cells were also compared for statistically significant changes to nonstimulated cells (basal expression). All statistical significance data are summarized in Supplemental Tables S1 and S2. Data are expressed as means \pm SEM. 
than in the Cyp46a1 ${ }^{-/-}$RMM. In BMDM, the $L x r$ expression

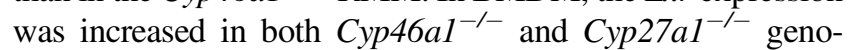
types, with increases being higher for the $\alpha$ isoform (up to 2.4 -fold) than the $\beta$ isoform (up to 1.2-fold) and for the Cyp46al ${ }^{-/-}$genotype than the Cyp27al ${ }^{-1-}$ genotype (Figure 7C). In the Cyp27a1 ${ }^{-1-}$ Cyp46a1 ${ }^{-1-}$ BMDM, the Lxr expression was isoform specific, with a slight (1.2-fold) increase in the $L x r \alpha$ expression and essentially unchanged $\operatorname{Lxr} \beta$ expression. Thus, the Cyp46a1 ${ }^{-1-}$ and Cyp $27 a 1^{-1-}$ genotypes demonstrated different effects on the $L x r$ expression in RMM but not BMDM, and changes in the expression of Lxr $\alpha$ were more pronounced in RMM than BMDM.

\section{Genes that Are Transactivated by LXRs}

In RMM, all of the tested genes, except Mertk, were upregulated in the Cyp46a1 ${ }^{-1-}$ genotype (up to 175-fold, ArgII) (Figure 7E). In contrast, in the Cyp27a1 ${ }^{-1-}$ RMM, changes in the gene expression were highly variable (ie, gene specific), with the gene expression being unchanged (Apod and Idol), decreased (Abcal and Mertk, up to 1.4fold), or increased (Abcgl, Apoe, and ArgII, up to fivefold). Consequently, in the Cyp27al ${ }^{-1-} C_{y p} 46 a 1^{-1-}$ RMM, the gene expression was mostly increased (up to 5.3-fold, Apoe) with the exception of Idol, which had an unchanged expression, and Merk, whose expression was decreased 1.3fold. Similar to the Cyp46a1 $1^{-1-} \mathrm{RMM}$, the Cyp46a1 ${ }^{-/-}$ BMDM had an up-regulated expression of more than half of the tested genes (four of seven), yet the extent of upregulation was much smaller, only up to 1.8 -fold (Figure 7F). Also, some of the genes that showed increased expression in the Cyp46a1 ${ }^{-/-}$RMM (Apod, Apoe, and $A r g I I)$ were not up-regulated in the Cyp46al ${ }^{-1-}$ BMDM and vice versa (Mertk). In the Cyp27a1 ${ }^{-\prime-}$ BMDM, the gene expression was unchanged (Abcgl and Apoe), decreased (Abcal, up to 1.3-fold), or increased (Apod, ArgII, Idol, and Mertk, up to 1.6-fold), like in the Cyp27a1 ${ }^{-1}$ RMM, except the genes that showed the same direction of a change did not completely overlap in the Cyp27a1 ${ }^{-1-}$ RMM and Cyp27a1 ${ }^{-1-}$ BMDM. The latter likely led to a different pattern of gene changes in the Cyp27a1 ${ }^{-/}{\text {Cyp } 46 a 1^{-/}}^{-}$BMDM relative to the Cyp $27 a 1^{-1-}$ Cyp $46 a 1^{-1-}$ RMM: in the former, only one gene was slightly (1.2-fold) up-regulated (Apod), and the expression of the remaining genes was either unchanged (Abcl, Abcgl, and Idol) or decreased (Apoe, ArgII, and Mertk). Thus, changes in the gene expression were not identical in RMM and BMDM; however, in both, the Cyp46a1 ${ }^{-1-}$ genotype up-regulated the expression of the LXR transactivated gene, although to a different extent. A higher gene up-regulation in the Cyp46al ${ }^{-1}$ RMM than Cyp46a1 ${ }^{-1-}$ BMDM could be due to a higher up-regulation of the Lxr expression in the Cyp46a1 ${ }^{-1}$ RMM than Cyp46a1 $1^{-1-}$ BMDM. Also possible, in both Cyp46a1 $1^{-1-}$ RMM and Cyp46a1 ${ }^{-1-}$ BMDM, there were oxysterol ligands (likely $27 \mathrm{HC}$ and/or $27 \mathrm{COOH}$ ) that compensated for a lack of $24 \mathrm{HC}$. In contrast, in both Cyp $27 a 1^{-1-} \mathrm{RMM}$ and
Cyp27al ${ }^{-/}$BMDM, the effect of the knockout genotype was gene specific.

\section{Genes that Are Transrepressed by LXRs}

In the Cyp46a1 ${ }^{-1-}$ RMM, all of the tested genes were upregulated (up to 41,199-fold, iNos), whereas in the Cyp $27 a 1^{-1-}$ RMM, only three genes (Ccl2, iNos, and Tnfa) had an increased expression (up to 21-fold) (Figure 7I). The levels of the remaining four genes were either unchanged (Cox-2) or decreased (Cxcll, Il-1 $\beta$, and Il-6, up to fivefold). Nevertheless, in the Cyp27a1 ${ }^{-/-}$Cyp46al ${ }^{-/-}$RMM, all of the tested genes were up-regulated as well (up to 176-fold, Cxcl1), as observed in the Cyp46a1 ${ }^{-1-}$ genotype. In BMDM, the pattern of changes in the gene expression was in general similar to that in RMM, with an increase in the gene expression in the Cyp46al ${ }^{-1-}$ genotype and genespecific responses in the Cyp27a1 $1^{-1-}$ genotype (Figure $7 \mathrm{~J}$ ). The differences from RMM were both the smaller number of up-regulated genes and low magnitude of gene up-regulation. Indeed, only four genes in the Cyp46a1 ${ }^{-1-}$ BMDM (Ccl2, Cox-2, Cxcll, and Il-6), one gene in the Cyp27a1 ${ }^{-1-}$ BMDM (Cxcll), and five genes in the Cyp27a1 ${ }^{-1-} C_{y p 46 a 1^{-1-}}$ BMDM (Ccl2, Cox-2, Cxcll, Il-6, and iNos) had an increased expression ranging from 1.3-fold (Tnfa in the Cyp27a1 ${ }^{-/}$Cyp46a1 ${ }^{-/-}$BMDM) to 2.7-fold ( $\mathrm{Ccl} 2$ in the $C y p 46 a 1^{-1-}$ BMDM). Thus, within each knockout genotype, the pattern of changes in the expression of the LXR transrepressed genes was similar in RMM and BMDM and was similar to that of the LXR transactivated genes. The latter was unexpected because normally, LXR activation has opposite effects on the expression of the transactivated and transrepressed genes. ${ }^{52}$ Yet, this was not the case for the Cyp46a1 ${ }^{-1-}$ RMM and BMDM, suggesting that in the Cyp46al ${ }^{-/}$genotype, LXRmediated gene transrepression is dissociated from LXRmediated gene transactivation.

\section{Gene Expression in the LPS-Activated Macrophages}

Studies have shown that in macrophages with unchanged LXR expression, the induction of the LXR transactivated genes is profoundly inhibited by bacterial and viral pathogens as well as their components, which act through toll-like receptors 3 and 4 and an interferon regulatory factor 3 -dependent pathway. ${ }^{52,53}$ Conversely, signaling through toll-like receptor 4 or receptors for Il-1 $\beta$ and Tnfa is attenuated by cell or animal treatments with synthetic LXR ligands or genetic manipulations to achieve a constitutively active LXR. ${ }^{28,54,55}$ Hence, it was tested whether a lack of CYP46A1 or/and CYP27A1 affected LXR activity in cultured macrophages activated by LPS, a toll-like receptor 4 ligand. ${ }^{56}$ Data analysis included a comparison of the gene expression in stimulated cells of the wild-type genotypes versus that in the corresponding nonstimulated cells (Supplemental Tables S1 and S2). Also, stimulated cells of the knockout genotypes were compared with the stimulated 
wild-type cells and then with the corresponding nonstimulated cells.

Lxrs

The levels of $L x r \alpha$ and $L x r \beta$ were increased greater than threefold in the stimulated wild-type C57BL/6J;129S6/SvEv RMM and essentially unchanged $(<1.2$-fold difference in the gene expression) in the stimulated wild-type C57BL/6J RMM (Figure 7B). Nevertheless, the stimulated RMM of the Cyp $46 a 1^{-1-}$ and $C y p 27 a 1^{-1-}$ genotypes showed a decrease in the $L x r$ expression relative to that in the stimulated wild-type cells (up to 5.5-fold) as well as the corresponding nonstimulated cells (up to sixfold). The effect of LPS on the $L x r$ expression in BMDM was isoform specific (Figure 7D). In both stimulated wild-type and knockout cells, $\operatorname{Lxr} \beta$ but not Lxr $\alpha$ showed a uniform down-regulation of the expression relative to that in the corresponding nonstimulated cell. Thus, compared with the $L x r$ expression in the stimulated wild-type cells, only in the stimulated RMM but not BMDM, the Cyp $46 a 1^{-1-}$ and Cyp27a1 ${ }^{-1-}$ genotypes had a clear downregulating effect on the gene expression.

\section{Genes that Are Transactivated by LXRs}

The effect of LPS treatment of RMM from wild-type C57BL/ $6 \mathrm{~J} ; 129 \mathrm{~S} 6 / \mathrm{SvEv}$ mice was gene specific (Figure 7G). The gene expression was unchanged (Abcgl and Apoe), decreased (up to twofold, Abcal and Merk), or increased [moderately (up to 2.5-fold, Apod and Idol) or substantially (58-fold, ArgII)]. Gene-specific responses were also observed in the stimulated RMM from wild-type C57BL/6 J mice. Yet, in the stimulated Cyp46a1 ${ }^{-/-}$and Cyp46a1 ${ }^{-1-}$ Cyp $27 a 1^{-1-}$ RMM, the LPS effect was more uniform [ie, mostly led to an increase in the gene expression (up to 18.8fold, $A b c g 1$ ) relative to that in the stimulated wild-type cells and comparable gene expression (within a 1.5 -fold change) relative to that in the corresponding nonstimulated cells]. The two exceptions were Idol and Mertk. In contrast, the gene expression in the stimulated Cyp27a1 ${ }^{-1-}$ RMM was moderately decreased (up to twofold, Abcal and Idol) relative to that in the stimulated wild-type cells; however, it was comparable to that in the corresponding nonstimulated cells. The two exceptions were Apoe and ArgII. In BMDM, all of the genotypes responded to the LPS treatment similarly [namely, had a canonical down-regulation of the gene expression (up to 10-fold, Abcal) relative to that in the corresponding nonstimulated cells] (Figure $7 \mathrm{H}$ ). Notably, this down-regulated gene expression was comparable between wild-type and knockout gene expression. The two exceptions were Apod and ArgII. Thus, in the stimulated RMM, the Cyp46a1 ${ }^{-/-}$and Cyp $27 a 1^{-1-}$ genotypes mostly had opposite, up- and down-regulating effects, respectively, on the expression of the transactivated genes relative to that in the stimulated wild-type cells. Apparently, the $\mathrm{Cyp} 46 \mathrm{al}^{-/-}$genotype ablated the suppressing LPS effect on the LXR

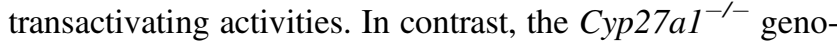
type retained this effect; despite stimulated RMM, it had the
Lxr expression significantly down-regulated in both knockout genotypes compared with that in the stimulated wild-type cells. In the stimulated BMDM, the knockout genotype effect cannot be assessed because it could be masked by a significant reduction in the expression of most of the tested genes.

\section{Genes that Are Transrepressed by LXRs}

In RMM from both wild-type genotypes, the LPS stimulation led to an expected substantial up-regulation of all of the studied genes: up to 1860-fold (iNos) in the C57BL/ $6 \mathrm{~J} ; 129 \mathrm{~S} 6 / \mathrm{SvEv}$ cells and up to 378 -fold $(\mathrm{Ccl} 2)$ in the C57BL/6J cells (Figure 7K). Similarly, an up-regulated gene expression (comparable to that in the stimulated wild-type RMM and the corresponding nonstimulated cells) was also observed in the stimulated Cyp46a1 ${ }^{-1-}$ RMM. The three exceptions were Il-1 $\beta$, iNos, and Tnfa. In the stimulated Cyp27a1 ${ }^{-1-}$ and Cyp46a1 ${ }^{-/-}$Cyp27a1 ${ }^{-/-}$RMM, the gene expression was either unchanged or lower (up to threefold, $C c l 2$ ) than that in the stimulated wild-type RMM and much higher (up to 120-fold, Cxcll) than the gene expression in the corresponding nonstimulated cells. The exceptions in these genotypes were Il-1 $\beta$ and Tnfa. Like the stimulated wild-type RMM, the stimulated wild-type BDDM also had uniform increases in the gene expression: up to 31,303-fold (iNos) in the C57BL/6J;129S6/SvEv cells and up to 9335 -fold (iNos) in the C57BL/6J cells (Figure 7L). Yet, there was no knockout genotype effect on the gene expression in the stimulated BMDM; the levels of most of the genes were comparable to that in the stimulated wild-type cells and much higher than the gene expression in the corresponding nonstimulated cells. The two exceptions were $\mathrm{Ccl} 2$ and iNos. Thus, in RMM and BMDM, the transrepressed genes in the knockout genotypes responded differently to the LPS stimulation. In the stimulated RMM, only the Cyp $27 a 1^{-/}$genotype had a down-regulating effect on the expression of the transrepressed genes relative to that in the stimulated wild-type cells. This suggests that the LXR activity that antagonizes gene transrepression was higher in the Cyp27a1 ${ }^{-1-}$ RMM than the Cyp46a1 ${ }^{-1-}$ RMM. In contrast, in the stimulated BMDM, there was no effect of the knockout genotype on the gene expression, which was always much higher than that in the corresponding nonstimulated cells; the knockout genotype effect in these cells could be masked by already significantly up-regulated gene expression in the stimulated wild-type cells.

\section{RMM Activation in Vivo}

Retinal flat mounts and cross sections were stained for F4/80 and Iba1, respectively, markers for microglia/macrophage activation. ${ }^{57}$ The F4/80-positive cells were detected in the inner retina of $C y p 46 a 1^{-1-}$ mice but not anywhere in the wild-type retina (Figure 8A). The detected F4/80-positive cells had stout bodies and short processes, indicative of the activated state. Similarly, the Iba1-positive cells were clearly 
detected in retinal cross sections of $\mathrm{Cyp} 4 \mathrm{ar} \mathrm{I}^{-/-}$mice (Figure 8B). Yet in wild-type mice (Figure 8C), there were only few Iba1-positive cells, thus suggesting that RMMs are activated in vivo in the Cyp46a1 ${ }^{-1-}$ genotype.

\section{Gene Expression in Retinal Endothelial Cells and RPE}

Both chronic inflammation and dyslipidemia contribute to vascular damage in diabetes, ${ }^{1,58}$ consistent with the data on RMM activation (Figure 7), disturbance of retinal cholesterol homeostasis (Figure 1), and retinal vascular abnormalities in Cyp46a1 ${ }^{-/}$mice (Figure 4). In addition, retinal endothelial cells are involved, which are affected by the proinflammatory environment in the diabetic retina, and whose injury in diabetes plays a key role in retinal vascular degeneration. ${ }^{59}$ Hence, CYP46A1 gene expression was first assessed in primary HRECs from nondiabetic and diabetic donors and we also evaluated the expression of CYP27A1 (Figure 9), which is known to be abundant in human aortic endothelium. ${ }^{60}$ In both nondiabetic and diabetic donors, there was a significant interdonor variability in primary HRECs with respect to the Ct numbers for CYP46Al and CYP27A1: the mean $\mathrm{Ct}$ for CYP46Al was approximately 27.0, and for CYP27A1, approximately 30.0. These numbers suggest that the transcript abundance is intermediate for CYP46Al and lower for CYP27A1. Yet, a high interdonor variability in $\mathrm{Ct}$ numbers for both CYPs precluded a conclusion about changes (if any) in HREC expression of CYP46Al and CYP27Al in diabetes. Hence, the Cyp expression was next evaluated in BRECs, which were stimulated by Tnfa to mimic the proinflammatory environment in the retina. In BRECs, the treatment with Tnfa upregulated Cyp46al twofold and did not affect the expression of Cyp27al.

RPE, which expresses both CYP46A1 and CYP27A1, , ,11,12 was of interest to us as well to gain insight into whether CYP46A1 and CYP27A1 expression is affected similarly in different cell types by the proinflammatory stimulus. In Tnfatreated RPE, the Cyp46al expression was reduced greater than threefold, and the expression of Cyp27al was reduced 1.3fold. Apparently, Tnfa-induced changes in the cytochrome P450 expression are P450 and cell specific. Finally, CYP46A1 immunolocalization was conducted in retinal flat mounts and cross sections, which were also stained for CD31, a marker of vascular endothelial cells, or neuronal-specific nuclear protein, a DNA-binding protein that identifies many populations of mature neurons. ${ }^{61,62}$ In both flat mounts and cross sections, the immunoreactivity for CYP46A1 overlapped in part with that for CD31 (Figure 10A). There was also CYP46A1 immunoreactivity outside retinal blood vessels, which could reflect CYP46A1 expression in some of the retinal neurons. The latter was confirmed by double stains for CYP46A1 and neuronalspecific nuclear protein, which identified partial overlaps in immunoreactivity (Figure 10B). Thus, CYP46A1 seems to be expressed in some, but not all, retinal vascular endothelial cells as well as neurons. Neuronal CYP46A1 expression in the retina is consistent with that in the brain, where CYP46A1 was found to be distributed throughout the cell bodies and dendrites of multiple neurons. ${ }^{12}$

\section{Retinal Phosphoproteomics in Cyp46a1-/- Mice}

LXR $\alpha$ can be modified by phosphorylation, which affects its transcriptional activities. ${ }^{63-66}$ Also, in Cyp46a1 ${ }^{-1-}$ mice, the phosphorylation of 146 proteins was altered in the brain. ${ }^{42}$ Hence, retinal phosphoproteome was studied. A total of 31 phosphopeptides from 30 distinct proteins showed a statistically significant difference in abundance between the Cyp46a1 ${ }^{-1-}$ and wild type retinas (Table 2). Of these peptides, 28 phosphopeptides from 27 proteins were more abundant in the knockout retina than the wild-type retina, including 12 phosphopeptides that were found only in the Cyp46a1 $1^{-1-}$ retina. Fewer phosphopeptides (only three from different proteins: Ras GTPase-activating protein-binding
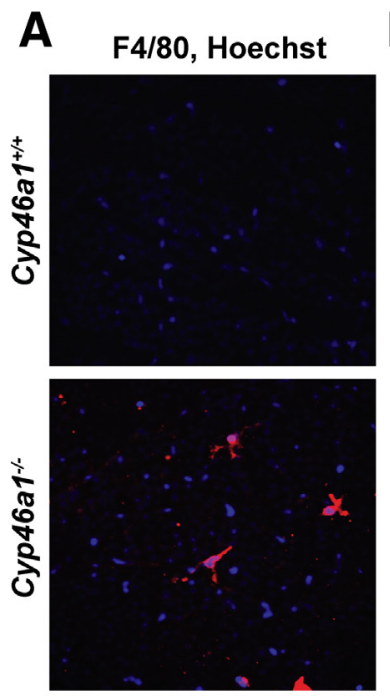
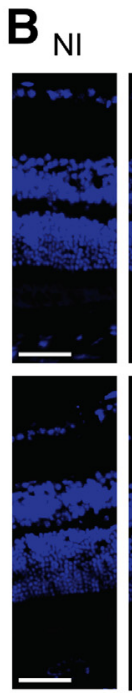
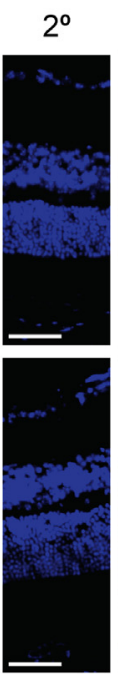

Iba1, DAPI

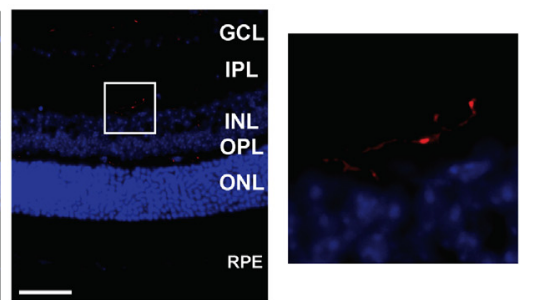

GCL

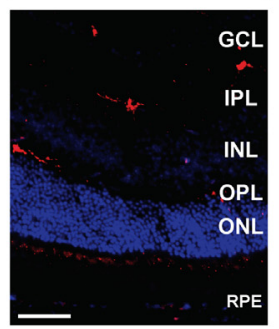

Figure 8 Macrophage/microglia activation in the Cyp46a1 ${ }^{-/-}$retina. A and B: Representative stains of retinal flat mounts for $\mathrm{F} 4 / 80$ (red; $\mathbf{A}$ ) and retinal cross sections for Iba1 (red; B); nuclei were stained with Hoechst (blue) and DAPI (blue), respectively. C: Enlargement of the boxed area in B showing wild-type retina with Iba1-positive cells. $n=3$ (A and B). Scale bars $=50 \mu \mathrm{m}$ (B). Original magnification, $\times 200$ (A). $2^{\circ}$, Control stain using secondary antibody only; GCL, ganglion cell layer; INL, inner nuclear layer; IPL, inner plexiform layer; NI, control stain using nonimmune serum; $\mathrm{ONL}$, outer nuclear layer; $\mathrm{OPL}$, outer plexiform layer; RPE, retinal pigment epithelium. 
A

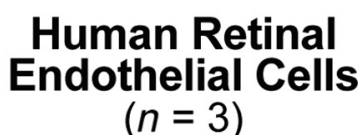

Nondiabetic

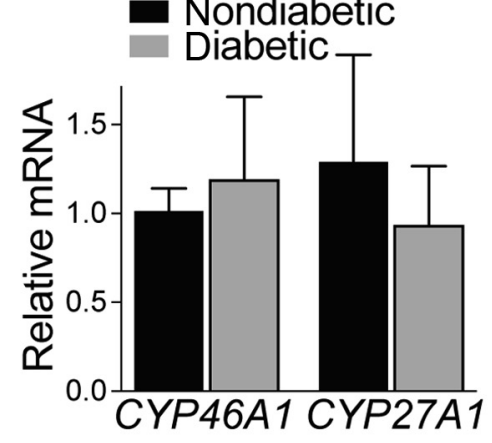

B

Bovine Retinal Endothelial Cells

$(n=3)$

Untreated

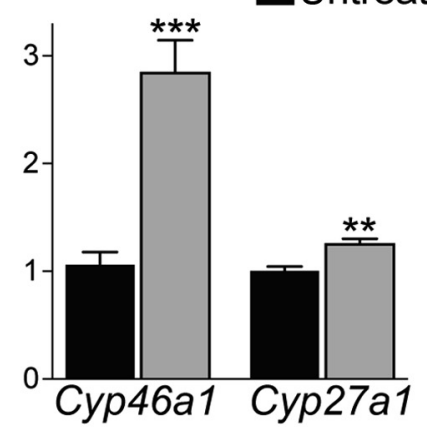

C Bovine Retinal
Pigment Epithelium $(n=3)$

Figure 9 Cyp46a1 and Cyp27a1 expression in different cell types. The results are triplicate measurements of cells from three different donors (A) or three different cell preparations (B and $\mathbf{C}$ ). Asterisks are significant changes relative to untreated cells (B and $\mathbf{C}$ ), as assessed by a two-tailed, unpaired $t$-test. Data are expressed as means \pm SEM. ${ }^{* *} P \leq 0.01,{ }^{* * *} P \leq 0.001$ versus untreated cells.

protein 1, putative RNA-binding protein Luc7-like 2, and dihydropyrimidinase-related protein 3 ) were more abundant in the Cyp46a1 ${ }^{+/+}$than Cyp46a1 ${ }^{-1-}$ retina. Two of the differentially phosphorylated retinal proteins were protein kinases: calcium/calmodulin-dependent protein kinase kinase 1 and brain-specific serine/threonine-protein kinase 2 . The remaining proteins were pertinent to at least five general biological processes: i) information transfer (gene transcription and translation, mRNA binding, stability, and processing: 11 proteins); ii) neuritogenesis (six proteins); iii) cytoskeleton maintenance (five proteins); iv) membrane vesicle trafficking (three proteins); and v) signal transduction (three proteins).
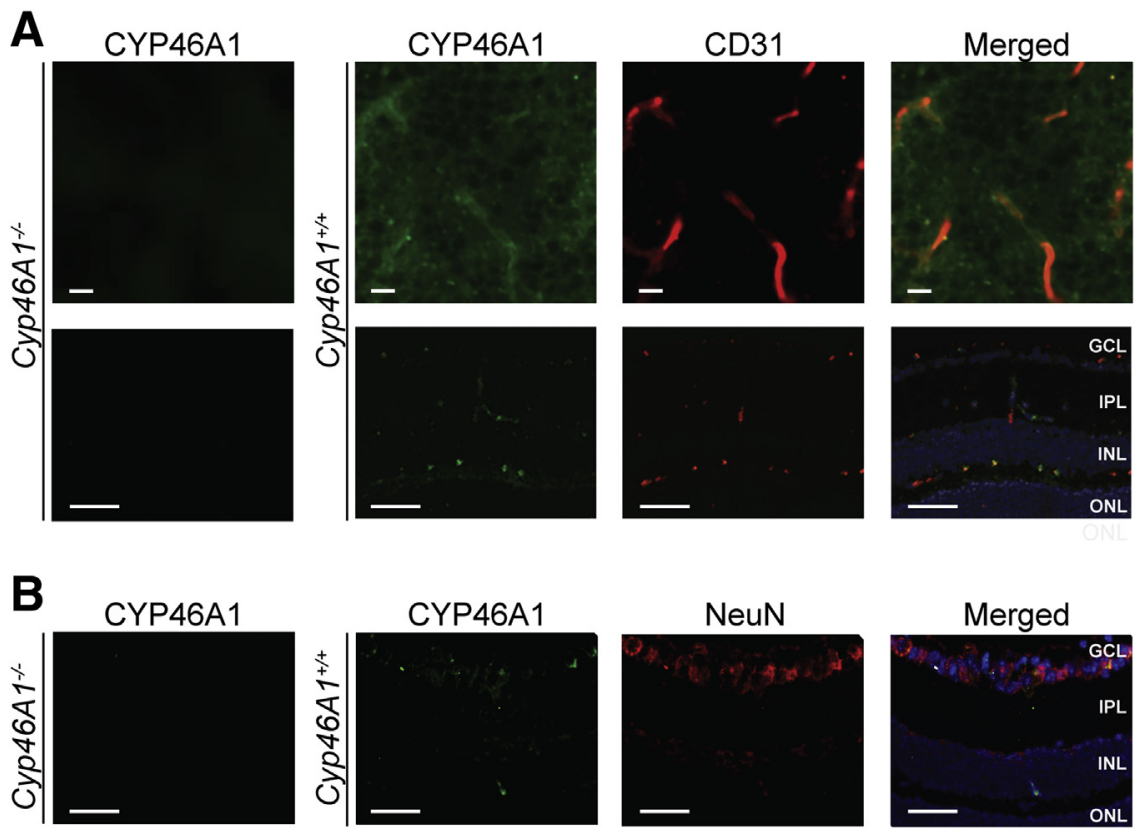

\section{Discussion}

The present study led to several major findings. First, some of the features of early-stage diabetic retinopathy were observed in Cyp46a1 ${ }^{-1-}$ mice (Figure 4), which exhibited a slight decrease in fasting blood glucose levels but had delayed glucose clearance in a glucose tolerance test (Figure 5). In addition, Cyp46a1 ${ }^{-/-}$mice showed up to a 1.8-fold increase in total retinal cholesterol (Figure 1A). Second, the Cyp46al ${ }^{-1-}$ retina had an up-regulated expression of both $\operatorname{Lxr} \alpha / \operatorname{Lx} \beta$ and several of the proinflammatory genes (Ccl2, Cox-2, Cxcll, iNos, and Tnfa) that are normally suppressed by LXRs (Figure 6). Similarly, 
Table 2 Phosphoproteins with Different Phosphopeptide Abundance in the Cyp46a1-/- Retina Compared with the Wild-Type Retina

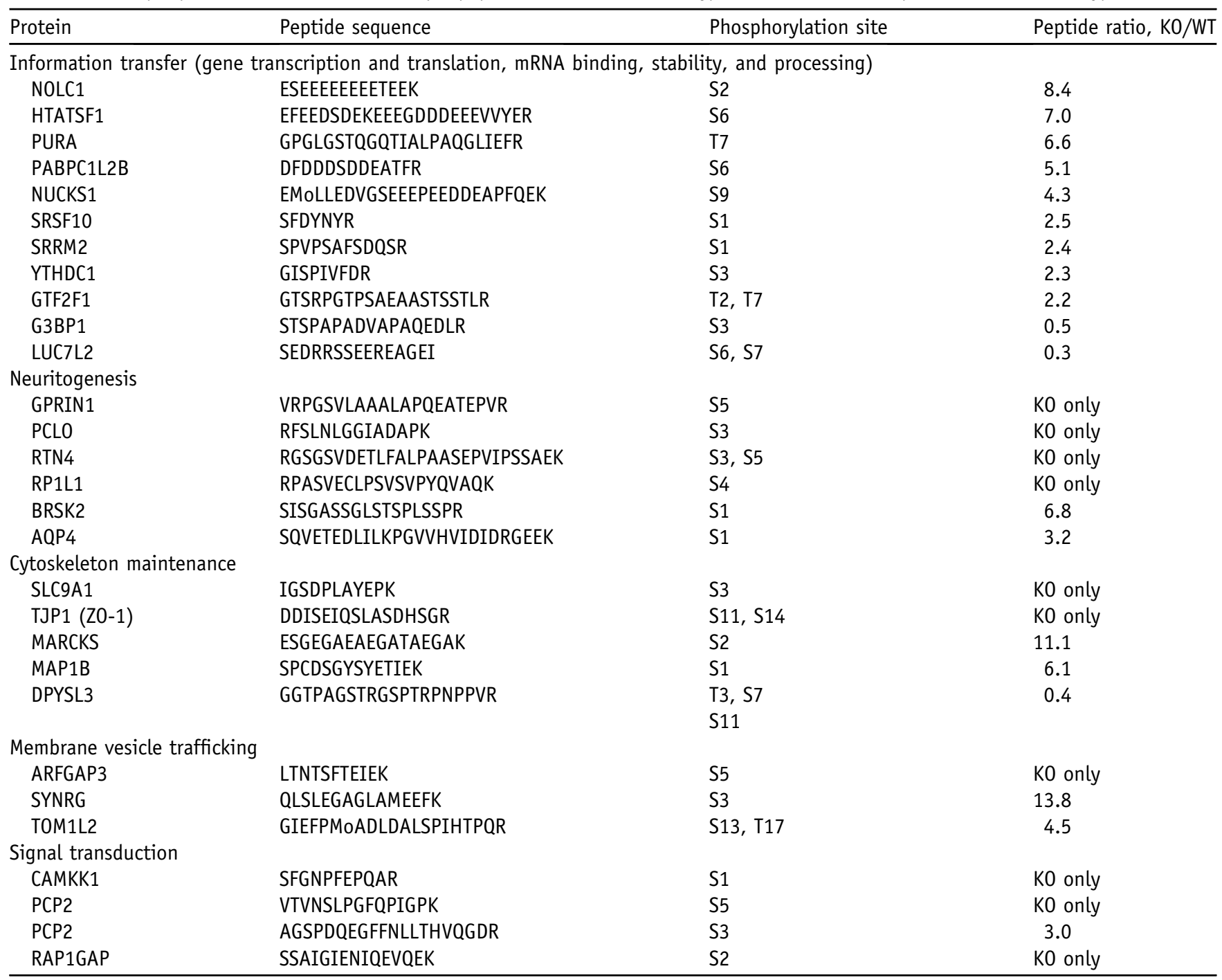

Involvement in only one biological process is indicated for each protein, although many proteins participate in more than one biological process.

AQP4, aquaporin-4 isoform M23A; ARFGAP3, ADP-ribosylation factor GTPase-activating protein 3; BRSK2, brain-specific serine/threonine-protein kinase 2; CAMKK1, calcium/calmodulin-dependent protein kinase kinase 1; DPYSL3, dihydropyrimidinase-related protein 3; G3BP1, Ras GTPase-activating proteinbinding protein 1; GPRIN1, G-protein-regulated inducer of neurite outgrowth 1 isoform X1; GTF2F1, general transcription factor IIF subunit 1 isoform X1; HTATSF1, HIV Tat-specific factor 1 homolog; K0, Cyp46a1 ${ }^{-1-}$ retina; LUC7L2, putative RNA-binding protein Luc7-like 2; MAP1B, microtubule-associated protein 1B isoform X1; MARCKS, myristoylated alanine-rich C-kinase substrate; Mo, oxidized methionine; NOLC1, nucleolar and coiled-body phosphoprotein 1 isoform B; NUCKS1, nuclear ubiquitous casein and cyclin-dependent kinase substrate 1 isoform 1; PABPC1L2B, polyadenylate-binding protein 1-like 2; PCL0, protein piccolo isoform X4; PCP2, Purkinje cell protein 2 isoform 1; PURA, transcriptional activator protein Pur- $\alpha$ isoform X1; RAP1GAP, rap1 GTPase-activating protein 1 isoform 3; RP1L1, retinitis pigmentosa 1-like 1 protein; RTN4, reticulon-4 isoform A; SLC9A1, sodium/hydrogen exchanger 1 isoform X2; SRRM2, serine/arginine repetitive matrix protein 2; SRSF10, serine/arginine-rich splicing factor 10 isoform 2; SYNRG, synergin $\gamma$; TJP1, tight junction protein Z0-1 isoform 2; TOM1L2, target of Myb protein 1 isoform X1; WT, wild-type retina; YTHDC1, YTH domain-containing protein 1 isoform X6; Z0-1, zonula occludens 1.

Lxrs and many of the proinflammatory genes $(C c l 2, \operatorname{Cox}-2$, Cxcll, Il-1 $\beta$, Il-6, iNos, and Tnfa) were up-regulated in the Cyp46a1 ${ }^{-1-}$ RMM, suggesting a decrease in LXRtransrepressing activities (Figure 7I). Yet, the LXRtransactivating activities were increased in the Cyp46a1 ${ }^{-1-}$ RMM (Figure 7E) and affected both cholesterol-related genes (Abcal, Abcgl, Apod, Apoe, and Idol) and a gene of macrophage function (ArgII). Third, changes in the gene expression in the Cyp46a1 ${ }^{-1-}$ genotype were much more pronounced in the RMM than BMDM. Finally, CYP46A1 appears to be expressed in retinal vascular endothelial cells, and CYP46A1 gene expression is increased in proinflammatory conditions.

Recent evidence suggests that changes to retinal microglia are an early feature of diabetic retinopathy. ${ }^{48}$ Microglia are also altered in experimental models of diabetic retinopathy ${ }^{67}$ Yet, the causes and consequences of microglial changes in diabetic retinopathy are not fully understood. 
The causes might be retinal formation of molecules produced as a result of hyperglycemia ${ }^{48,68}$ and/or a systemic low-grade inflammation present chronically in diabetes. ${ }^{1,69}$ The consequences could be neuronal death ${ }^{48,70}$ and retinal vascular dysfunction. ${ }^{59,67}$ The latter was inferred from the findings that microglia play an important role in formation and maintenance of the retinal vasculature ${ }^{71}$ and are present in diabetic retinas near dilated veins, microaneurysms, vitreal neovascularizations, hemorrhages, and cotton-wool spots. ${ }^{47}$ Activated microglia produce cytokines and thus can contribute to vascular and neural damage in diabetic retina. ${ }^{59} \mathrm{Cyp}_{46 \mathrm{al}}{ }^{-1-}$ mice have changes to both, RMM and retinal vasculature, and hence support the notion that microglia (and infiltrating macrophages) contribute to retinal vascular dysfunction. In addition, Cyp46a1 ${ }^{-1-}$ mice represent an interesting model of RMM activation (Figures 7 and 8) when there is no serum hyperglycemia (Figure 5). Physically, Cyp46a1 ${ }^{-/-}$mice are outwardly normal, ${ }^{31,33}$ likely because tissue expression of CYP46A1 is largely confined to the brain and retina. $12,33,72$

There are probably several causes of RMM activation in Cyp46a1 ${ }^{-/-}$mice: i) a significantly increased retinal cholesterol content and/or a lack of retinal $24 \mathrm{HC}$; ii) an increased $L x r$ expression in both, the whole retina and RMM, assuming this increase enhances LXR activation by oxysterols; and iii) distinct roles of 24- and 27-oxysterols in LXR transactivation and transrepression in RMM. Indeed, normally, microglia are actively monitoring the retinal microenvironment and may be activated in Cyp46a1 ${ }^{-1}$ mice by the increased cholesterol content of the retina (Figure 1A). In addition, the Cyp46a1 ${ }^{-1-}$ RMM might be activated by a lack of $24 \mathrm{HC}$. This would be similar to retinal glial cells, shown to be activated by a decrease in retinal $24 \mathrm{HC}$ as a result of pharmacologic CYP46A1 inhibition with voriconazole. ${ }^{73}$ Atypical (nonneuronal) CYP46A1 expression in brain astrocytes and microglia seems to be a common feature of various pathologic conditions in the brain. ${ }^{12,74-77}$ It is possible that the retina could have a similar feature, and RMM activation in response to different stimuli (eg, disturbed sterol content) triggers CYP46A1 expression in these cells. In the Cyp46a1 ${ }^{-1-}$ RMM, LXRtransactivating activity (and the corresponding gene expression) could be increased because of increased $L x r$ expression and/or the presence of the activating ligands other than $24 \mathrm{HC}$ (eg, desmosterol, $27 \mathrm{OH}, 27 \mathrm{COOH}$, and/or other oxysterols). LXR-transrepressing activity might be decreased because $24 \mathrm{HC}$, the major activating ligand, is absent, and/or LXR activation by $27 \mathrm{HC}, 27 \mathrm{COOH}$, and/or other sterols does not suppress the inflammatory gene expression.

Different effects of oxysterol/sterol ligands on LXR transactivation and transrepression in the RMM explain the dissociation of the two LXR activities in these cell types and are supported by the gene expression pattern in the knockout genotypes. A much lower expression of the LXRtransactivated genes in the Cyp27al ${ }^{-/-} \mathrm{Cyp}_{46 a 1^{-1-}} \mathrm{RMM}$ than $C y p 46 a 1^{-/-}$RMM suggests an important contribution of $27 \mathrm{HC}$ or $27 \mathrm{COOH}$ to the RMM LXR transactivation; unchanged or increased gene expression in the Cyp27al ${ }^{-/}$ RMM highlights the involvement in this process of $24 \mathrm{HC}$ and perhaps other ligands (Figure 7E). Conversely, 27HC or $27 \mathrm{COOH}$ in the Cyp46a1 ${ }^{-1-} \mathrm{RMM}$ was generally not sufficient for LXR transrepression, emphasizing the importance of 24HC (and possibly other ligands) for the suppression of inflammatory genes in the activated RMM. The 24HC importance is also supported by unchanged (or even decreased) expression of Cox-2, Cxcll, Il-1 $\beta$, and Il-6 but not Ccl2, iNos, and Tnfa in the Cyp27a1 ${ }^{-1}$ RMM (Figure 7I). Thus, 27HC, 27COOH, 24HC, and possibly other sterols/oxysterols appear to be important for LXR transactivation, whereas 24HC (but not 27HC and $27 \mathrm{COOH})$ seems to be important for LXR transrepression. This explanation is consistent with previous studies showing that $25 \mathrm{HC}$ and $27 \mathrm{HC}$ act in thioglycolate-elicited macrophages as transactivators only, whereas 22R-hydroxycholesterol, 24,25-epicholesterol, and 24HC induce both LXR transactivation and transrepression. ${ }^{26}$ Moderate changes in the expression of LXR-dependent genes in BMDM (Figure 7, F and J) suggest that either CYP46A1 and CYP27A1 are not expressed in these cells or oxysterols produced by these P450s are not involved in the LXR activation in BMDM. Apparently, the retina is much more sensitive to a lack of CYP46A1 than the bone marrow, thus establishing the importance of CYP46A1 for the retina, in addition to enzyme roles in brain cholesterol maintenance and higher-order brain functions. ${ }^{78}$

A significant up-regulation of $L x r \alpha$ and $L x r \beta$ in the whole Cyp46a1 ${ }^{-1-}$ retina (Figure 6) and RMM (Figure 7A) is an unexpected finding. Lxr $\alpha$ was also found to be up-regulated in the brain of $C y p 46 a 1^{-1-} .42$ Transcriptional regulation of LXRs includes Lxr $\alpha$ autoregulation ${ }^{79}$ and regulation by fatty acids, ${ }^{80}$ thyroid hormone, ${ }^{81}$ certain cytokines (TNF- $\alpha$ and Il-1 $\beta),{ }^{82,83}$ and interferon $-\gamma{ }^{83}$ In addition, $\operatorname{Lx} \alpha$ can be alternatively spliced, leading to the production of three $\mathrm{LXR} \alpha$ isoforms ( $\mathrm{LXR} \alpha 1$ to 3 ), with $\mathrm{LXR} \alpha 2$ having a reduced transcriptional activity and LXR $\alpha 3$ being transcriptionally inactive. ${ }^{84}$ LXR $\beta$ could also be alternatively spliced and produce the LXRBSV variant, which selectively enhances LXR $\beta$-mediated transactivation. ${ }^{85}$ The expression of Tnfa and Il-1 $\beta$ was increased in the Cyp46a1 ${ }^{-/-}$RMM (Figure 7I), but it is not clear whether this increase is the cause or consequence of $L x r \alpha$ up-regulation. Also, this increase does not explain the up-regulation of $\operatorname{Lxr} \beta$. Remarkably, studies of the retinal Cyp46a1 ${ }^{-1-}$ phosphoproteomics identified altered phosphorylation of 11 different proteins (the largest number of proteins per functional group) involved in transmission of genetic information (Table 2). It is conceivable that some of these proteins are involved in the control of the $L x r$ levels, and their altered phosphorylation increases the levels of $L x r \alpha$ and $\operatorname{Lxr} \beta$ in the Cyp $46 a 1^{-/-}$retina. Of course, this is only a speculation, and future studies are required to identify the unknown factors 
that up-regulate the expression of $L x r \alpha$ and $L x r \beta$ in the $C y p 46 a 1^{-1-}$ retina and brain. Regardless of the cause of $L x r$ up-regulation, the present work and previous studies of

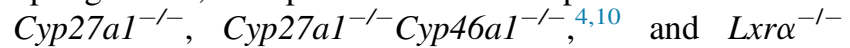
$\operatorname{Lxr} \beta^{-1-}$ mice ${ }^{15}$ suggest that aberrant LXR signaling plays an important role in the development of vascular abnormalities typical for early-stage diabetic retinopathy. Moreover, the development of these changes does not require such features of diabetes as hyperglycemia and chronic systemic inflammation.

Studies of retinal phosphoproteomics indicate that microglia activation might not be the only factor contributing to retinal vascular abnormalities in Cyp $46 a 1^{-1-}$ mice. The modulation of protein phosphorylation could contribute as well because oxysterols and cholesterol were shown to modulate membrane function and receptor molecules associated with plasma and subcellular membranes. ${ }^{86-88}$ The phosphorylation of tight junction protein zonula occludens 1, or ZO-1 (TJP1), and aquaporin 4 (AQP4) (Table 2) may be of particular relevance to retinal vascular abnormalities in Cyp46a1 ${ }^{-1-}$ mice. ZO-1 is a key scaffolding protein necessary for the formation of tight junctions in various tissues. ${ }^{89,90}$ In the retina, ZO-1 is a part of tight junctions of the outer retinal blood barrier (formed by the RPE) and the inner retinal blood barrier (formed by the blood vessels of the neural retina). ${ }^{91}$ Deletion of ZO-1 is embryonically lethal because of impaired formation of vascular trees and defective chorioallantoic fusion in yolk sac. ${ }^{92}$ Studies show that reduced expression of tight junction proteins, including ZO-1, leads to increased blood-retinal barrier permeability, which is closely linked to angiogenesis. ${ }^{93,94}$ Vascular changes in diabetic retinopathy are due, at least in part, to elevated vascular endothelial growth factor expression, ${ }^{94}$ and ZO-1 was found to be phosphorylated after vascular endothelial growth factor stimulation of bovine aortic endothelial cells. ${ }^{95}$ This phosphorylation was suggested to inactivate ZO-1, whereas ZO-1 down-regulation was established to enhance endothelial cell proliferation. ${ }^{95}$ In the present work, ZO-1 seems to be only phosphorylated in the Cyp46a1 $1^{-1-}$ retina, thus raising a possibility that this phosphorylation contributes, at least in part, to increased vascular permeability and other retinal vascular abnormalities in Cyp46a1 ${ }^{-1-}$ mice.

AQP4 is another protein in Cyp46a1 ${ }^{-/-}$mice, whose increased retinal phosphorylation could be of pertinence to the Cyp46a1 ${ }^{-1-}$ retinal phenotype (Table 2). AQP4 is a member of a large family of membrane protein channels that facilitate transport of water and small solutes. ${ }^{96} \mathrm{AQP} 4$ is the predominant aquaporin in mammalian retina with a prominent localization around blood vessels (it is mainly present in the perivascular and end feet of Muller cells and astrocytes). ${ }^{96,97}$ Both expression and localization of AQP4 are altered in experimental diabetes, ${ }^{98-101}$ and AQP4 knockdown was found to exacerbate streptozotocin-induced diabetic retinopathy (retinal vascular permeability, retinal thickness, and vascular endothelial growth factor expression) through increased inflammatory response. ${ }^{101}$ Studies of $A q p 4^{-/-}$mice report the following: mild ERG changes with no changes in retinal ultrastructure ${ }^{102}$; increased retinal glutamate levels ${ }^{103}$; low-level retinal inflammation along with increased retinal susceptibility to osmotic stress ${ }^{104}$; and the dysfunction of the blood-retinal barrier as well as reactive gliosis. ${ }^{105}$ Phosphorylated AQP4 was found in several tissues but not the retina; hence, physiological significance of retinal AQP4 phosphorylation is not yet clear. Nevertheless, a role of AQP4 in water transport, ${ }^{96}$ expression around retinal blood vessels, ${ }^{97}$ and changes in expression and localization in experimental diabetes ${ }^{98-101}$ raise a possibility that increased phosphorylation of AQP4 in the Cyp46a1 $1^{-1-}$ retina is of relevance to the changes of retinal vasculature. Future research is required to ascertain retinal significance of $\mathrm{ZO}-1$ and $\mathrm{AQP} 4$ phosphorylation.

Overall, the Cyp46a1 ${ }^{-/-}$retina had much less differentially phosphorylated peptides than the Cyp46a1 ${ }^{-1-}$ brain (31 retinal phosphopeptides versus 185 brain phosphopeptides), with 28 retinal peptides having increased phosphorylation (Table 2). In contrast, in the brain, 151 phosphopeptides were less abundant in Cyp46a1 ${ }^{-1-}$ mice. ${ }^{42}$ Also, only two proteins (microtubuleassociated protein $1 \mathrm{~B}$ isoform $\mathrm{X} 1$ and myristoylated alanine-rich C-kinase substrate) and three protein isoforms (dihydropyrimidinase-related protein 3, rap1 GTPase-activating protein 1 isoform 3, and reticulon) were common in retinal and brain phosphoproteomics, suggesting that a lack of CYP46A1 elicits organ-specific changes in protein phosphorylation.

Beside effects on protein phosphorylation and microglia activation, CYP46A1 could be directly involved in maintenance of retinal vasculature, as indicated by the CYP46AI mRNA and protein expression in retinal vascular endothelial cells (Figures 9 and 10). Indeed, CYP46A1 is a cholesteroleliminating enzyme, and clinical studies support the role of lipids in vascular damage in diabetic retinopathy; moreover, they suggest that retinal lipid levels may be more critical than the circulating lipid levels. ${ }^{58}$ Increased Cyp46al levels in BREC in response to TNF- $\alpha$ stimulation could be protective because this Cyp46al up-regulation may increase the cellular 24HC concentration and LXR activation and thereby downregulate the expression of the proinflammatory genes. Thus, in addition to metabolism of cholesterol and LXR regulation in RMM, CYP46A1 could potentially mediate (via LXRs) the anti-inflammatory effects in retinal vascular endothelial cells and be even involved in cellular antiadhesive properties, as demonstrated for artery endothelial cells. ${ }^{106}$

The present work and previous studies of LXRs ${ }^{15}$ suggest that increasing LXR activities would ameliorate retinal inflammation. A tiny dose of the anti-HIV drug efavirenz activates CYP46A1 and increases tissue $24 \mathrm{HC}$ concentrations in mouse brain ${ }^{107,108}$ and retina (data not shown). Efavirenz treatment also ameliorates the manifestations of Alzheimer disease in a mouse model of this disease (5XFAD mice). ${ }^{108}$ Perhaps, efavirenz should be tested on a mouse model of diabetic retinopathy for the effect on retinal vascular abnormalities. 
In summary, ablation of Cyp46al in mice led to some of the manifestations of early-stage diabetic retinopathy, retinal increase in total cholesterol, and a significant up-regulation of key proinflammatory genes in both the whole retina and RMM but not BMDM. These data establish CYP46A1 roles in retinal cholesterol homeostasis and regulation of retinal immune response. In addition, CYP46A1 may have other roles, as suggested by studies of retinal endothelial cells and retinal phosphoproteome. The present work supports the importance of LXRs in the retina and brings attention to CYP46A1 as a potential new player in diabetic retinopathy and a target that can be activated pharmacologically.

\section{Acknowledgments}

We thank Joseph Lin for contributions to retinal phosphoproteomics; the Visual Sciences Research Center Core Facilities for assistance with mouse breeding (Heather Butler and Kathryn Franke), animal genotyping (John Denker), tissue sectioning (Catherine Doller), and microscopy (Anthony Gardella); Yan Levitsky (Michigan State University) for image acquisition; Dr. Belinda Willard (Proteomics Laboratory, Cleveland Clinic Foundation) for conducting retinal phosphoproteomics; Dr. David Russell (UT Southwestern) for providing Cyp46a1 ${ }^{+/-}$mice; and Dr. Sandra Erickson (University of California, San Francisco) for providing Cyp27al ${ }^{+/-}$mice.

\section{Supplemental Data}

Supplemental material for this article can be found at https://doi.org/10.1016/j.jmoldx.2018.10.013.

\section{References}

1. Tang J, Kern TS: Inflammation in diabetic retinopathy. Prog Retin Eye Res 2011, 30:343-358

2. Durham JT, Herman IM: Microvascular modifications in diabetic retinopathy. Curr Diab Rep 2011, 11:253-264

3. Stitt AW, Lois N, Medina RJ, Adamson P, Curtis TM: Advances in our understanding of diabetic retinopathy. Clin Sci (Lond) 2013, 125 : $1-17$

4. Saadane A, Mast N, Charvet C, Omarova S, Zheng W, Huang SS, Kern TS, Peachey NS, Pikuleva IA: Retinal and non-ocular abnormalities in Cyp27a1-/- Cyp64a1-/- mice with dysfunctional metabolism of cholesterol. Am J Pathol 2014, 184:2403-2419

5. Wikvall K: Hydroxylations in biosynthesis of bile acids: isolation of a cytochrome P-450 from rabbit liver mitochondria catalyzing 26hydroxylation of C27-steroids. J Biol Chem 1984, 259:3800-3804

6. Lund EG, Guileyardo JM, Russell DW: cDNA cloning of cholesterol 24-hydroxylase, a mediator of cholesterol homeostasis in the brain. Proc Natl Acad Sci U S A 1999, 96:7238-7243

7. Liao WL, Heo GY, Dodder NG, Reem RE, Mast N, Huang S, Dipatre PL, Turko IV, Pikuleva IA: Quantification of cholesterolmetabolizing P450s CYP27A1 and CYP46A1 in neural tissues reveals a lack of enzyme-product correlations in human retina but not human brain. J Proteome Res 2011, 10:241-248
8. Zheng W, Reem RE, Omarova S, Huang S, DiPatre PL, Charvet CD, Curcio CA, Pikuleva IA: Spatial distribution of the pathways of cholesterol homeostasis in human retina. PLoS One 2012, 7:e37926

9. Mast N, Reem R, Bederman I, Huang S, DiPatre PL, Bjorkhem I, Pikuleva IA: Cholestenoic acid is an important elimination product of cholesterol in the retina: comparison of retinal cholesterol metabolism with that in the brain. Invest Ophthalmol Vis Sci 2011, 52:594-603

10. Omarova S, Charvet CD, Reem RE, Mast N, Zheng W, Huang S, Peachey NS, Pikuleva IA: Abnormal vascularization in mouse retina with dysregulated retinal cholesterol homeostasis. J Clin Invest 2012 , 122:3012-3023

11. Lee JW, Fuda H, Javitt NB, Strott CA, Rodriguez IR: Expression and localization of sterol 27-hydroxylase (CYP27A1) in monkey retina. Exp Eye Res 2006, 83:465-469

12. Ramirez DM, Andersson S, Russell DW: Neuronal expression and subcellular localization of cholesterol 24-hydroxylase in the mouse brain. J Comp Neurol 2008, 507:1676-1693

13. Meaney S, Bodin K, Diczfalusy U, Bjorkhem I: On the rate of translocation in vitro and kinetics in vivo of the major oxysterols in human circulation: critical importance of the position of the oxygen function. J Lipid Res 2002, 43:2130-2135

14. Janowski BA, Willy PJ, Devi TR, Falck JR, Mangelsdorf DJ: An oxysterol signalling pathway mediated by the nuclear receptor LXR alpha. Nature 1996, 383:728-731

15. Hazra S, Rasheed A, Bhatwadekar A, Wang X, Shaw LC, Patel M, Caballero S, Magomedova L, Solis N, Yan Y, Wang W, Thinschmidt JS, Verma A, Li Q, Levi M, Cummins CL, Grant MB: Liver $\mathrm{X}$ receptor modulates diabetic retinopathy outcome in a mouse model of streptozotocin-induced diabetes. Diabetes 2012, 61: 3270-3279

16. Hammer SS, Beli E, Kady N, Wang Q, Wood K, Lydic TA, Malek G, Saban DR, Wang XX, Hazra S, Levi M, Busik JV, Grant MB: The mechanism of diabetic retinopathy pathogenesis unifying key lipid regulators, sirtuin 1 and liver $\mathrm{X}$ receptor. EBioMedicine 2017, 22: $181-190$

17. Chen W, Chen G, Head DL, Mangelsdorf DJ, Russell DW: Enzymatic reduction of oxysterols impairs LXR signaling in cultured cells and the livers of mice. Cell Metab 2007, 5:73-79

18. Spann NJ, Garmire LX, McDonald JG, Myers DS, Milne SB, Shibata N, Reichart D, Fox JN, Shaked I, Heudobler D, Raetz CR, Wang EW, Kelly SL, Sullards MC, Murphy RC, Merrill AH Jr, Brown HA, Dennis EA, Li AC, Ley K, Tsimikas S, Fahy E, Subramaniam S, Quehenberger O, Russell DW, Glass CK: Regulated accumulation of desmosterol integrates macrophage lipid metabolism and inflammatory responses. Cell 2012, 151:138-152

19. Willy PJ, Umesono K, Ong ES, Evans RM, Heyman RA, Mangelsdorf DJ: LXR, a nuclear receptor that defines a distinct retinoid response pathway. Genes Dev 1995, 9:1033-1045

20. Auboeuf D, Rieusset J, Fajas L, Vallier P, Frering V, Riou JP, Staels B, Auwerx J, Laville M, Vidal H: Tissue distribution and quantification of the expression of mRNAs of peroxisome proliferator-activated receptors and liver $\mathrm{X}$ receptor-alpha in humans: no alteration in adipose tissue of obese and NIDDM patients. Diabetes $1997,46: 1319-1327$

21. Apfel R, Benbrook D, Lernhardt E, Ortiz MA, Salbert G, Pfahl M: A novel orphan receptor specific for a subset of thyroid hormoneresponsive elements and its interaction with the retinoid/thyroid hormone receptor subfamily. Mol Cell Biol 1994, 14:7025-7035

22. Wagner BL, Valledor AF, Shao G, Daige CL, Bischoff ED, Petrowski M, Jepsen K, Baek SH, Heyman RA, Rosenfeld MG, Schulman IG, Glass CK: Promoter-specific roles for liver X receptor/corepressor complexes in the regulation of ABCA1 and SREBP1 gene expression. Mol Cell Biol 2003, 23:5780-5789

23. Glass CK, Rosenfeld MG: The coregulator exchange in transcriptional functions of nuclear receptors. Genes Dev 2000, 14:121-141

24. Spann NJ, Glass CK: Sterols and oxysterols in immune cell function. Nat Immunol 2013, 14:893-900 
25. Calkin AC, Tontonoz P: Transcriptional integration of metabolism by the nuclear sterol-activated receptors LXR and FXR. Nat Rev Mol Cell Biol 2012, 13:213-224

26. Ghisletti S, Huang W, Ogawa S, Pascual G, Lin ME, Willson TM, Rosenfeld MG, Glass CK: Parallel SUMOylation-dependent pathways mediate gene- and signal-specific transrepression by LXRs and PPARgamma. Mol Cell 2007, 25:57-70

27. Jakobsson T, Treuter E, Gustafsson JA, Steffensen KR: Liver X receptor biology and pharmacology: new pathways, challenges and opportunities. Trends Pharmacol Sci 2012, 33:394-404

28. Joseph SB, Castrillo A, Laffitte BA, Mangelsdorf DJ, Tontonoz P: Reciprocal regulation of inflammation and lipid metabolism by liver X receptors. Nat Med 2003, 9:213-219

29. Bischoff ED, Daige CL, Petrowski M, Dedman H, Pattison J, Juliano J, Li AC, Schulman IG: Non-redundant roles for LXRalpha and LXRbeta in atherosclerosis susceptibility in low density lipoprotein receptor knockout mice. J Lipid Res 2010, 51:900-906

30. Dwyer MA, Kazmin D, Hu P, McDonnell DP, Malek G: Research resource: nuclear receptor atlas of human retinal pigment epithelial cells: potential relevance to age-related macular degeneration. Mol Endocrinol 2011, 25:360-372

31. Lund EG, Xie C, Kotti T, Turley SD, Dietschy JM, Russell DW: Knockout of the cholesterol 24-hydroxylase gene in mice reveals a brain-specific mechanism of cholesterol turnover. J Biol Chem 2003, 278:22980-22988

32. Dubrac S, Lear SR, Ananthanarayanan M, Balasubramaniyan N, Bollineni J, Shefer S, Hyogo H, Cohen DE, Blanche PJ, Krauss RM, Batta AK, Salen G, Suchy FJ, Maeda N, Erickson SK: Role of CYP27A in cholesterol and bile acid metabolism. J Lipid Res 2005, 46:76-85

33. Russell DW, Halford RW, Ramirez DM, Shah R, Kotti T: Cholesterol 24-hydroxylase: an enzyme of cholesterol turnover in the brain. Annu Rev Biochem 2009, 78:1017-1040

34. Mast N, Shafaati M, Zaman W, Zheng W, Prusak D, Wood T, Ansari GA, Lovgren-Sandblom A, Olin M, Bjorkhem I, Pikuleva I: Marked variability in hepatic expression of cytochromes CYP7A1 and CYP27A1 as compared to cerebral CYP46A1: lessons from a dietary study with omega 3 fatty acids in hamsters. Biochim Biophys Acta 2010, 1801:674-681

35. Kohno H, Chen Y, Kevany BM, Pearlman E, Miyagi M, Maeda T, Palczewski K, Maeda A: Photoreceptor proteins initiate microglial activation via Toll-like receptor 4 in retinal degeneration mediated by all-trans-retinal. J Biol Chem 2013, 288:15326-15341

36. Earle WR, Schilling EL, Stark TH, Straus NP, Brown MF, Shelton E: Production of malignancy in vitro, IV: the mouse fibroblast cultures and changes seen in the living cells. J Natl Cancer Inst 1943, 4: $165-212$

37. Jaffe GJ, Earnest K, Fulcher S, Lui GM, Houston LL: Antitransferrin receptor immunotoxin inhibits proliferating human retinal pigment epithelial cells. Arch Ophthalmol 1990, 108:1163-1168

38. Wang Q, Bozack SN, Yan Y, Boulton ME, Grant MB, Busik JV: Regulation of retinal inflammation by rhythmic expression of MiR146a in diabetic retina. Invest Ophthalmol Vis Sci 2014, 55: 3986-3994

39. Wang H, Han X, Wittchen ES, Hartnett ME: TNF-alpha mediates choroidal neovascularization by upregulating VEGF expression in RPE through ROS-dependent beta-catenin activation. Mol Vis 2016, 22:116-128

40. Pfaffl MW: A new mathematical model for relative quantification in real-time RT-PCR. Nucleic Acids Res 2001, 29:e45

41. Tual-Chalot S, Allinson KR, Fruttiger M, Arthur HM: Whole mount immunofluorescent staining of the neonatal mouse retina to investigate angiogenesis in vivo. J Vis Exp 2013, 77:e50546

42. Mast N, Lin JB, Anderson KW, Bjorkhem I, Pikuleva IA: Transcriptional and post-translational changes in the brain of mice deficient in cholesterol removal mediated by cytochrome P450 46A1 (CYP46A1). PLoS One 2017, 12:e187168
43. Saadane A, Mast N, Dao T, Ahmad B, Pikuleva IA: Retinal hypercholesterolemia triggers cholesterol accumulation and esterification in photoreceptor cells. J Biol Chem 2016, 291:20427-20439

44. Radu M, Chernoff J: An in vivo assay to test blood vessel permeability. J Vis Exp 2013, 73:e50062

45. Horton JD, Goldstein JL, Brown MS: SREBPs: activators of the complete program of cholesterol and fatty acid synthesis in the liver. J Clin Invest 2002, 109:1125-1131

46. Im SS, Yousef L, Blaschitz C, Liu JZ, Edwards RA, Young SG, Raffatellu M, Osborne TF: Linking lipid metabolism to the innate immune response in macrophages through sterol regulatory element binding protein-1a. Cell Metab 2011, 13:540-549

47. Zeng HY, Green WR, Tso MO: Microglial activation in human diabetic retinopathy. Arch Ophthalmol 2008, 126:227-232

48. Grigsby JG, Cardona SM, Pouw CE, Muniz A, Mendiola AS, Tsin AT, Allen DM, Cardona AE: The role of microglia in diabetic retinopathy. J Ophthalmol 2014, 2014:705783

49. Tesch GH: Role of macrophages in complications of type 2 diabetes. Clin Exp Pharmacol Physiol 2007, 34:1016-1019

50. Duh EJ, Sun JK, Stitt AW: Diabetic retinopathy: current understanding, mechanisms, and treatment strategies. JCI Insight 2017, 2: e93751

51. Waddington KE, Jury EC, Pineda-Torra I: Liver X receptors in immune cell function in humans. Biochem Soc Trans 2015, 43: $752-757$

52. Zelcer N, Tontonoz P: Liver X receptors as integrators of metabolic and inflammatory signaling. J Clin Invest 2006, 116:607-614

53. Castrillo A, Joseph SB, Vaidya SA, Haberland M, Fogelman AM, Cheng G, Tontonoz P: Crosstalk between LXR and toll-like receptor signaling mediates bacterial and viral antagonism of cholesterol metabolism. Mol Cell 2003, 12:805-816

54. Ogawa D, Stone JF, Takata Y, Blaschke F, Chu VH, Towler DA, Law RE, Hsueh WA, Bruemmer D: Liver x receptor agonists inhibit cytokine-induced osteopontin expression in macrophages through interference with activator protein-1 signaling pathways. Circ Res 2005, 96:e59-e67

55. Hong C, Walczak R, Dhamko H, Bradley MN, Marathe C, Boyadjian R, Salazar JV, Tontonoz P: Constitutive activation of LXR in macrophages regulates metabolic and inflammatory gene expression: identification of ARL7 as a direct target. J Lipid Res 2011, 52: $531-539$

56. Beutler B, Hoebe K, Du X, Ulevitch RJ: How we detect microbes and respond to them: the Toll-like receptors and their transducers. J Leukoc Biol 2003, 74:479-485

57. Santos AM, Calvente R, Tassi M, Carrasco MC, Martin-Oliva D, Marin-Teva JL, Navascues J, Cuadros MA: Embryonic and postnatal development of microglial cells in the mouse retina. J Comp Neurol 2008, 506:224-239

58. Hammer SS, Busik JV: The role of dyslipidemia in diabetic retinopathy. Vision Res 2017, 139:228-236

59. Chakravarthy H, Beli E, Navitskaya S, O'Reilly S, Wang Q, Kady N, Huang C, Grant MB, Busik JV: Imbalances in mobilization and activation of pro-inflammatory and vascular reparative bone marrowderived cells in diabetic retinopathy. PLoS One 2016, 11:e0146829

60. Reiss AB, Martin KO, Rojer DE, Iyer S, Grossi EA, Galloway AC, Javitt NB: Sterol 27-hydroxylase: expression in human arterial endothelium. J Lipid Res 1997, 38:1254-1260

61. Rakocevic J, Orlic D, Mitrovic-Ajtic O, Tomasevic M, Dobric M, Zlatic N, Milasinovic D, Stankovic G, Ostojic M, LabudovicBorovic M: Endothelial cell markers from clinician's perspective. Exp Mol Pathol 2017, 102:303-313

62. Buckingham BP, Inman DM, Lambert W, Oglesby E, Calkins DJ, Steele MR, Vetter ML, Marsh-Armstrong N, Horner PJ: Progressive ganglion cell degeneration precedes neuronal loss in a mouse model of glaucoma. J Neurosci 2008, 28:2735-2744

63. Chen M, Bradley MN, Beaven SW, Tontonoz P: Phosphorylation of the liver X receptors. FEBS Lett 2006, 580:4835-4841 
64. Yamamoto T, Shimano H, Inoue N, Nakagawa Y, Matsuzaka T, Takahashi A, Yahagi N, Sone H, Suzuki H, Toyoshima H, Yamada N: Protein kinase A suppresses sterol regulatory elementbinding protein-1C expression via phosphorylation of liver $\mathrm{X}$ receptor in the liver. J Biol Chem 2007, 282:11687-11695

65. Wu C, Hussein MA, Shrestha E, Leone S, Aiyegbo MS, Lambert WM, Pourcet B, Cardozo T, Gustafson JA, Fisher EA, Pineda-Torra I, Garabedian MJ: Modulation of macrophage gene expression via liver $\mathrm{X}$ receptor alpha serine 198 phosphorylation. Mol Cell Biol 2015, 35:2024-2034

66. Huang W, Ghisletti S, Saijo K, Gandhi M, Aouadi M, Tesz GJ, Zhang DX, Yao J, Czech MP, Goode BL, Rosenfeld MG, Glass CK: Coronin 2A mediates actin-dependent de-repression of inflammatory response genes. Nature 2011, 470:414-418

67. Abcouwer SF: Neural inflammation and the microglial response in diabetic retinopathy. J Ocul Biol Dis Infor 2011, 4:25-33

68. Zong H, Ward M, Stitt AW: AGEs, RAGE, and diabetic retinopathy. Curr Diab Rep 2011, 11:244-252

69. Zhang W, Liu H, Rojas M, Caldwell RW, Caldwell RB: Anti-inflammatory therapy for diabetic retinopathy. Immunotherapy 2011, 3: 609-628

70. Krady JK, Basu A, Allen CM, Xu Y, LaNoue KF, Gardner TW, Levison SW: Minocycline reduces proinflammatory cytokine expression, microglial activation, and caspase- 3 activation in a rodent model of diabetic retinopathy. Diabetes 2005, 54:1559-1565

71. Checchin D, Sennlaub F, Levavasseur E, Leduc M, Chemtob S: Potential role of microglia in retinal blood vessel formation. Invest Ophthalmol Vis Sci 2006, 47:3595-3602

72. Bretillon L, Diczfalusy U, Bjorkhem I, Maire MA, Martine L, Joffre C, Acar N, Bron A, Creuzot-Garcher C: Cholesterol-24S-hydroxylase (CYP46A1) is specifically expressed in neurons of the neural retina. Curr Eye Res 2007, 32:361-366

73. Fourgeux C, Martine L, Acar N, Bron AM, Creuzot-Garcher CP, Bretillon L: In vivo consequences of cholesterol-24S-hydroxylase (CYP46A1) inhibition by voriconazole on cholesterol homeostasis and function in the rat retina. Biochem Biophys Res Commun 2014 446:775-781

74. Bogdanovic N, Bretillon L, Lund EG, Diczfalusy U, Lannfelt L, Winblad B, Russell DW, Bjorkhem I: On the turnover of brain cholesterol in patients with Alzheimer's disease: abnormal induction of the cholesterol-catabolic enzyme CYP46 in glial cells. Neurosci Lett 2001, 314:45-48

75. Brown J 3rd, Theisler C, Silberman S, Magnuson D, GottardiLittell N, Lee JM, Yager D, Crowley J, Sambamurti K, Rahman MM, Reiss AB, Eckman CB, Wolozin B: Differential expression of cholesterol hydroxylases in Alzheimer's disease. J Biol Chem 2004, 279:34674-34681

76. Lavrnja I, Smiljanic K, Savic D, Mladenovic-Djordjevic A, Tesovic K, Kanazir S, Pekovic S: Expression profiles of cholesterol metabolism-related genes are altered during development of experimental autoimmune encephalomyelitis in the rat spinal cord. Sci Rep 2017, 7:2702

77. Cartagena CM, Ahmed F, Burns MP, Pajoohesh-Ganji A, Pak DT, Faden AI, Rebeck GW: Cortical injury increases cholesterol 24S hydroxylase (Cyp46) levels in the rat brain. J Neurotrauma 2008, 25: 1087-1098

78. Kotti TJ, Ramirez DM, Pfeiffer BE, Huber KM, Russell DW: Brain cholesterol turnover required for geranylgeraniol production and learning in mice. Proc Natl Acad Sci U S A 2006, 103:3869-3874

79. Whitney KD, Watson MA, Goodwin B, Galardi CM, Maglich JM, Wilson JG, Willson TM, Collins JL, Kliewer SA: Liver X receptor (LXR) regulation of the LXRalpha gene in human macrophages. J Biol Chem 2001, 276:43509-43515

80. Tobin KA, Steineger HH, Alberti S, Spydevold O, Auwerx J, Gustafsson JA, Nebb HI: Cross-talk between fatty acid and cholesterol metabolism mediated by liver $\mathrm{X}$ receptor-alpha. Mol Endocrinol 2000, 14:741-752
81. Hashimoto K, Matsumoto S, Yamada M, Satoh T, Mori M: Liver X receptor-alpha gene expression is positively regulated by thyroid hormone. Endocrinology 2007, 148:4667-4675

82. Kim MS, Sweeney TR, Shigenaga JK, Chui LG, Moser A, Grunfeld C, Feingold KR: Tumor necrosis factor and interleukin 1 decrease RXRalpha, PPARalpha, PPARgamma, LXRalpha, and the coactivators SRC-1, PGC-1alpha, and PGC-1beta in liver cells. Metabolism 2007, 56:267-279

83. Hao XR, Cao DL, Hu YW, Li XX, Liu XH, Xiao J, Liao DF, Xiang J, Tang CK: IFN-gamma down-regulates ABCA1 expression by inhibiting LXRalpha in a JAK/STAT signaling pathway-dependent manner. Atherosclerosis 2009, 203:417-428

84. Chen M, Beaven S, Tontonoz P: Identification and characterization of two alternatively spliced transcript variants of human liver $\mathrm{X}$ receptor alpha. J Lipid Res 2005, 46:2570-2579

85. Hashimoto K, Ishida E, Matsumoto S, Shibusawa N, Okada S, Monden T, Satoh T, Yamada M, Mori M: A liver X receptor (LXR)-beta alternative splicing variant (LXRBSV) acts as an RNA co-activator of LXR-beta. Biochem Biophys Res Commun 2009, 390:1260-1265

86. Bielska AA, Schlesinger P, Covey DF, Ory DS: Oxysterols as nongenomic regulators of cholesterol homeostasis. Trends Endocrinol Metab 2012, 23:99-106

87. Martin MG, Perga S, Trovo L, Rasola A, Holm P, Rantamaki T, Harkany T, Castren E, Chiara F, Dotti CG: Cholesterol loss enhances TrkB signaling in hippocampal neurons aging in vitro. Mol Biol Cell 2008, 19:2101-2112

88. Sodero AO, Trovo L, Iannilli F, Van Veldhoven P, Dotti CG, Martin MG: Regulation of tyrosine kinase B activity by the Cyp46/cholesterol loss pathway in mature hippocampal neurons: relevance for neuronal survival under stress and in aging. J Neurochem 2011, 116:747-755

89. Paris L, Tonutti L, Vannini C, Bazzoni G: Structural organization of the tight junctions. Biochim Biophys Acta 2008, 1778:646-659

90. Fanning AS, Anderson JM: Zonula occludens-1 and -2 are cytosolic scaffolds that regulate the assembly of cellular junctions. Ann N Y Acad Sci 2009, 1165:113-120

91. Ciolofan C, Li XB, Olson C, Kamasawa N, Gebhardt BR, Yasumura T, Morita M, Rash JE, Nagy JI: Association of connexin36 and zonula occludens- 1 with zonula occludens- 2 and the transcription factor zonula occludens-1-associated nucleic acid-binding protein at neuronal gap junctions in rodent retina. Neuroscience 2006, 140: 433-451

92. Katsuno T, Umeda K, Matsui T, Hata M, Tamura A, Itoh M, Takeuchi K, Fujimori T, Nabeshima Y, Noda T, Tsukita S, Tsukita S: Deficiency of zonula occludens-1 causes embryonic lethal phenotype associated with defected yolk sac angiogenesis and apoptosis of embryonic cells. Mol Biol Cell 2008, 19:2465-2475

93. Gardner TW: Histamine, ZO-1 and increased blood-retinal barrier permeability in diabetic retinopathy. Trans Am Ophthalmol Soc 1995, 93:583-621

94. Erickson KK, Sundstrom JM, Antonetti DA: Vascular permeability in ocular disease and the role of tight junctions. Angiogenesis 2007, 10 103-117

95. Chidiac R, Zhang Y, Tessier S, Faubert D, Delisle C, Gratton JP: Comparative phosphoproteomics analysis of VEGF and angiopoietin1 signaling reveals ZO-1 as a critical regulator of endothelial cell proliferation. Mol Cell Proteomics 2016, 15:1511-1525

96. Schey KL, Wang Z, L Wenke J, Qi Y: Aquaporins in the eye: expression, function, and roles in ocular disease. Biochim Biophys Acta 2014, 1840:1513-1523

97. Nagelhus EA, Veruki ML, Torp R, Haug FM, Laake JH, Nielsen S, Agre P, Ottersen OP: Aquaporin-4 water channel protein in the rat retina and optic nerve: polarized expression in Muller cells and fibrous astrocytes. J Neurosci 1998, 18:2506-2519

98. Iandiev I, Pannicke T, Reichenbach A, Wiedemann P, Bringmann A: Diabetes alters the localization of glial aquaporins in rat retina. Neurosci Lett 2007, 421:132-136 
99. Fukuda M, Nakanishi Y, Fuse M, Yokoi N, Hamada Y, Fukagawa M, Negi A, Nakamura M: Altered expression of aquaporins 1 and 4 coincides with neurodegenerative events in retinas of spontaneously diabetic Torii rats. Exp Eye Res 2010, 90:17-25

100. Kumar B, Gupta SK, Nag TC, Srivastava S, Saxena R, Jha KA, Srinivasan BP: Retinal neuroprotective effects of quercetin in streptozotocin-induced diabetic rats. Exp Eye Res 2014, 125: 193-202

101. Cui B, Sun JH, Xiang FF, Liu L, Li WJ: Aquaporin 4 knockdown exacerbates streptozotocin-induced diabetic retinopathy through aggravating inflammatory response. Exp Eye Res 2012, 98:37-43

102. Li J, Patil RV, Verkman AS: Mildly abnormal retinal function in transgenic mice without Muller cell aquaporin-4 water channels. Invest Ophthalmol Vis Sci 2002, 43:573-579

103. Li XM, Wendu RL, Yao J, Ren Y, Zhao YX, Cao GF, Qin J, Yan B: Abnormal glutamate metabolism in the retina of aquaporin 4 (AQP4) knockout mice upon light damage. Neurol Sci 2014, 35: $847-853$
104. Pannicke T, Wurm A, Iandiev I, Hollborn M, Linnertz R, Binder DK, Kohen L, Wiedemann P, Steinhauser C, Reichenbach A, Bringmann A: Deletion of aquaporin-4 renders retinal glial cells more susceptible to osmotic stress. J Neurosci Res 2010, 88:2877-2888

105. Nicchia GP, Pisani F, Simone L, Cibelli A, Mola MG, Dal Monte M, Frigeri A, Bagnoli P, Svelto M: Glio-vascular modifications caused by Aquaporin-4 deletion in the mouse retina. Exp Eye Res 2016, 146: 259-268

106. Calkin AC, Tontonoz P: Liver $\mathrm{x}$ receptor signaling pathways and atherosclerosis. Arterioscler Thromb Vasc Biol 2010, 30: $1513-1518$

107. Mast N, Li Y, Linger M, Clark M, Wiseman J, Pikuleva IA: Pharmacologic stimulation of cytochrome P450 46A1 and cerebral cholesterol turnover in mice. J Biol Chem 2014, 289:3529-3538

108. Mast N, Saadane A, Valencia-Olvera A, Constans J, Maxfield E, Arakawa H, Li Y, Landreth G, Pikuleva IA: Cholesterol-metabolizing enzyme cytochrome P450 46A1 as a pharmacologic target for Alzheimer's disease. Neuropharmacology 2017, 123:465-476 